\title{
A Capital Structure Channel of Monetary Policy
}

\author{
Grosse-Rueschkamp, Benjamin; Steffen, Sascha; Streitz, Daniel
}

Document Version

Accepted author manuscript

Published in:

Journal of Financial Economics

DOI:

10.1016/j.jfineco.2019.03.006

Publication date:

2019

\section{License \\ CC BY-NC-ND}

Citation for published version (APA):

Grosse-Rueschkamp, B., Steffen, S., \& Streitz, D. (2019). A Capital Structure Channel of Monetary Policy. Journal of Financial Economics, 133(2), 357-378. https://doi.org/10.1016/j.jineco.2019.03.006

Link to publication in CBS Research Portal

\section{General rights}

Copyright and moral rights for the publications made accessible in the public portal are retained by the authors and/or other copyright owners and it is a condition of accessing publications that users recognise and abide by the legal requirements associated with these rights.

Take down policy

If you believe that this document breaches copyright please contact us (research.lib@cbs.dk) providing details, and we will remove access to the work immediately and investigate your claim. 


\section{A Capital Structure Channel of Monetary Policy}

\section{Benjamin Grosse-Rueschkamp, Sascha Steffen, and Daniel Streitz}

Journal article (Accepted manuscript*)

\section{Please cite this article as:}

Grosse-Rueschkamp, B., Steffen, S., \& Streitz, D. (2019). A Capital Structure Channel of Monetary Policy. Journal of Financial Economics, 13321, 357-378. https://doi.org/10.1016/j.fineco.2019.03.006

DOl: https://doi.org/10.1016/j.jfineco.2019.03.006

* This version of the article has been accepted for publication and undergone full peer review but has not been through the copyediting, typesetting, pagination and proofreading process, which may lead to differences between this version and the publisher's final version AKA Version of Record.

Uploaded to CBS Research Portal: March २०२०

(C) २०19. This manuscript version is made available under the CC-BY-NC-ND 4.0 license http://creativecommons.org/licenses/by-nc-nd/4.0/ 


\title{
A Capital Structure Channel of Monetary Policy*
}

September 17, 2018

\begin{abstract}
We study the transmission channels from central banks' quantitative easing programs via the banking sector when central banks start purchasing corporate bonds. We find evidence consistent with a "capital structure channel" of monetary policy. The announcement of central bank purchases reduces the bond yields of firms whose bonds are eligible for central bank purchases. These firms substitute bank term loans with bond debt, thereby relaxing banks' lending constraints: banks with low Tier-1 ratios and high non-performing loans increase lending to private (and profitable) firms, which experience a growth in investment. The credit reallocation increases banks' risk-taking in corporate credit.
\end{abstract}

JEL Codes: G01, G21, G28

Keywords: debt capital structure, bond debt, unconventional monetary policy, quantitative easing, real effects 


\section{Introduction}

Since the start of the global financial crisis in late 2007, central banks around the world have implemented unconventional monetary policy measures to stimulate their economies, particularly through large-scale asset purchases (LSAPs). These programs are of significant size; for example, the balance sheet of the European Central Bank (ECB) has tripled since 2008 (to $€ 4.4$ trillion by early 2018). Recently, central banks have started programs that directly target nonfinancial corporations (NFCs), for example through large-scale corporate bond purchases. However, we know very little about the mechanisms of how these programs work. For example, how do corporate bond purchases affect financing choices of firms and how do these firms' responses, in turn, affect the banking sector? What are spillover effects of the purchase programs? Are they mediated through the banking sector and under what circumstances do they benefit or hurt the economy? These are questions that we explore in this paper.

Several channels for how LSAPs transmit to the real economy have been proposed in the literature, such as a signaling channel, duration risk channel, default risk or an inflation channel (see e.g. Krishnamurthy and Vissing-Jorgensen, 2011, for a discussion of these and other channels). Another important channel is the "net worth channel" that describes the pass-through of LSAPs to the real economy through bank balance sheets: central banks' asset purchases increase the price and the value of banks' asset holdings (e.g. mortgage-backed securities or Treasuries), which recapitalizes banks and stimulates lending. ${ }^{1}$

We propose a novel mechanism for how central banks' asset purchases can have a firstorder effect on the real sector. Motivated by theories that emphasize the importance of LSAPs on

\footnotetext{
${ }^{1}$ Recent empirical research attempts to identify the impact of LSAPs on the real economy via the bank lending channel (e.g. Chakraborty, Goldstein, and MacKinlay, 2017; Rodnyanski and Darmouni, 2017). Brunnermeier and Sannikov (2015) provide the theoretical framework for this channel.
} 
asset prices (e.g. Vayanos and Vila, 2009; Hanson and Stein, 2015; Krishnamurthy and VissingJorgensen, 2011, 2013), we hypothesize that direct corporate bond purchases by central banks decrease corporate bond yields. If bond financing becomes more attractive relative to bank loans, firms shift from bank loans into longer-term bonds. Banks thus experience a decline in loan demand, which reduces their regulatory or economic constraints and allows them to increase lending to other firms, generating spillovers to the real economy. In other words, central banks' purchases of corporate bonds can strengthen the bank lending channel because it changes the financing incentives of large firms with access to public debt. We call this the "capital structure channel" of monetary policy. To the best of our knowledge, this channel is new to the literature.

We examine this channel in the context of the ECB's corporate sector purchase programme (CSPP), which was announced on March 10, 2016 and implemented in June 2016. The ECB commenced monthly purchases of eligible corporate bonds in the eurozone and as of December 2017, total bond purchases exceeded $€ 130$ billion. The purchases are substantial and daily CSPP purchases account for $10 \%$ to $30 \%$ of the daily turnover of the entire investment-grade (IG) bond universe. Only high-quality, IG-rated bonds issued by NFCs are eligible under the CSPP. The CSPP is an ideal setting to study the capital structure channel, as eurozone banks usually do not hold NFC bonds on their balance sheets. ${ }^{2}$ Thus, banks are not directly affected by the CSPP through changes in their net worth.

We first show that eligible corporate bonds issued after the CSPP announcement carry substantially lower yields. This effect is particularly pronounced for bonds that are close to the eligibility threshold (i.e. BBB-rated bonds), which experience a decline in yield spreads of about

\footnotetext{
${ }^{2}$ The fraction of debt securities to total assets is on average $14 \%$ for monetary financial institutions (MFIs) in the eurozone; debt securities issued by NFCs account for about 3.5\% of the total stock of debt securities held by MFIs. That is, debt securities by NFCs account for less than $0.5 \%$ of MFIs' total assets. We provide detailed statistics in Appendix A.1.
} 
40 basis points (bps) over four quarters after the CSPP announcement relative to the four quarters before. We find no yield spread change for non-eligible bonds after the program announcement. Using the all publicly listed firms in Standard \& Poor's (S\&P) Capital IQ, we then identify the effect of the ECB's corporate bond purchases on eligible firms' debt capital structure decisions using a difference-in-differences (DiD) framework. As the ECB's decision to purchase specific corporate bonds is potentially endogenous and not all eligible bonds have been purchased under the CSPP, we use an "intention-to-treat" (ITT) approach and base our treatment definition on the eligibility of bonds prior to the announcement of the CSPP. The ITT approach provides an unbiased estimate of the average impact of a treatment on the group of eligible firms in a fully randomized experiment. In our setting, identification is not perfect as the treatment is not randomly assigned but is based on a potentially endogenous variable, i.e. a firm's IG rating. Unobservable bond demand of IG-rated firms after the announcement of the CSPP, for example, might influence their capital structure decision independent of the purchase program. We explore the sensitivity of our treatment effect to the inclusion of controls and fixed effects and argue that our estimates are likely to be in the lower bounds of the true effect of the CSPP. Our sample period is from Q1 2015 to Q1 2017 and the post-CSPP period begins in Q2 2016, as the program was announced in March 2016.

Our first main result is that eligible firms use bonds primarily as a substitute for bank (term) loans. Eligible firms increase their bond debt-to-assets ratio by 2 percentage points (pp) relative to non-eligible firms and relative to the period before the CSPP. This corresponds to a $13 \%$ increase in bond leverage relative to the unconditional mean. At the same time, eligible firms decrease their term loan-to-assets ratio by $1 \mathrm{pp}$, which corresponds to an $8 \%$ decrease relative to the unconditional mean. Within the set of eligible firms, we find that BBB-rated firms increase their bond debt-to- 
assets ratio more than AAA-A-rated firms $(+2.3$ pp vs. $+1.4 \mathrm{pp})$ and BBB-firms substitute bank debt (-1.6 pp term loans) with bond debt, leaving overall leverage unchanged. ${ }^{3}$ AAA-A-rated firms, in contrast, increase their leverage.

A variety of tests help us to rule out that our results are driven by factors unrelated to the CSPP. Among these factors are: (1) a significant pre-CSPP trend in bond financing for eligible versus non-eligible firms; (2) a general strengthening of the economy, which might differentially affect low-risk relative to high-risk firms; (3) a decrease in the supply of bank loans; (4) differences between treatment and control group firms; (5) the use of issue ratings of bonds issued pre-CSPP (as opposed to issuer ratings) to distinguish between treatment and control group firms; and (6) a scarcity of sovereign bonds due to ECB purchase programs. In summary, all results support our hypothesis that the CSPP announcement has a first-order effect on the debt capital structure of eligible firms, who shift from bank loans into corporate bonds.

This leads to the question of how the ECB's corporate bond purchases affect the real economy. We investigate two effects: (1) a direct effect on firms who have eligible bonds outstanding and (2) an indirect effect through spillovers on firms that benefit from an attenuation of banks' lending constraints. We first investigate the direct effect of the CSPP on the investment decisions of eligible firms but find no significant effects. This implies that these firms are not financially constrained and, more broadly, that an accommodative monetary policy has only limited effects on investments of these firms.

We then investigate spillovers to firms not directly affected by the CSPP. The capital structure channel of monetary policy predicts that a shift to bond markets by eligible firms reduces

\footnotetext{
${ }^{3}$ For example, in October 2016, the Spanish firm Amadeus refinanced a $€ 500$ million loan with a $€ 500$ million Eurobond with a longer duration than the facility and a lower coupon of $0.125 \%$. In the same month, Publicis Groupe partially repaid a bank loan with a long-term bond issuance of $€ 500$ million. In February 2017, Ryanair repaid longterm borrowings of $€ 447$ million with a $€ 750$ million Eurobond issuance. All companies are BBB-rated.
} 
bank capital constraints and stimulates lending to non-eligible firms. We use data from DealScan (Thomson Reuters LPC's database) to construct proxies related to the exposure of banks to eligible firms during the 2010 to 2014 period (before the CSPP). Moreover, we use DealScan data to construct a panel of bank-firm pairs in the pre- and post-CSPP period. In our main specification, we assess how a bank's exposure to eligible firms affects the likelihood that a firm receives a loan from that bank in the post-CSPP period. The key identifying assumption is that loan repayments are uncorrelated with other factors that affect bank lending. For identification, we exploit the fact that some firms are connected to more than one bank. That is, we use firm fixed effects to rule out that spillovers are driven by differences in the borrowers that are matched to banks with large or small exposure to eligible firms (Khwaja and Mian, 2008).

Our second main result is that the switch from bank loans to bond markets by eligible firms leads banks to increase lending to private firms (i.e. firms unlikely to be directly affected by the CSPP). These firms have an $8.8 \mathrm{pp}$ higher likelihood of obtaining a loan post-CSPP from banks with large exposure to CSPP-eligible firms. This corresponds to a $44 \%$ increase in the probability of obtaining a loan given an unconditional likelihood of issuing a loan of $20 \%$. In contrast, public firms, which usually have other outside funding options, do not experience an increase in lending. This is consistent with Holmstrom and Tirole (1997), who argue that an increase in intermediary capital increases the supply of loans to financially constrained firms. Our results cannot be explained by theories that emphasize the net worth channel and large-scale purchases of sovereign bonds by the ECB.

Consistent with the conjecture that the shift by eligible firms from private to public debt relaxes banks' lending constraints, we find that the effect is driven by banks with low Tier-1 ratios and high non-performing loans (NPLs). Moreover, firms that receive funding from these banks 
have above-median profitability and interest coverage ratios. This stands in contrast to an increase in lending to "zombie" firms during the European sovereign debt crisis, as shown by Acharya et al. (2017), among others. However, the shift in lending from high credit quality public firms to smaller private borrowers increases banks' loan portfolio risk. The average spread on new loans, a proxy for the riskiness of the borrower, increases by about one third relative to the pre-CSPP period for banks with large exposure to CSPP-eligible firms. Finally, we find that firms borrowing from banks with a lot of CSPP-eligible borrowers increase investment by $3.8 \mathrm{pp}$. This effect is economically large given an average pre-CSPP CapEx of 5.9\%.

It is noteworthy that the main effects of the corporate bond buying program are indirect. The monetary policy decision to commence large-scale purchases of corporate bonds causes banks to lose lending business from eligible firms, which banks then replace with lending to other firms. We coin this the "capital structure channel" of monetary policy. We show positive effects of this monetary policy channel as new lending to private firms seems to reduce financial constraints and increase investment. However, an alternative view is that this monetary policy change challenges financial sector stability in the long-run, as banks increase their exposure to riskier segments of the economy. We discuss this view and other implications in Section 7.

The paper proceeds as follows. We discuss the related literature and our contribution in Section 2. In Section 3, we describe the institutional framework and our methodology. The data are discussed in Section 4. We analyze the effect of the CSPP on the capital structure of eligible firms and their investment behavior in Section 5. In Section 6, we investigate the transmission mechanism into the real economy. We provide a broader discussion and concluding remarks in Section 7. 


\section{Related literature}

Our paper makes several contributions to the literature. Firstly, our paper is related to the literature on monetary policy and the bank lending channel (Kashyap and Stein, 1994; Peek and Rosengren, 2015). In this literature, banks with different balance sheets (e.g. different leverage and therefore different credit risk) respond differently to monetary policy shocks (Kashyap and Stein, 1995; 2000; Kishan and Opiela, 2000; Campello, 2002; Gambacorta and Mistrulli, 2004; Gomez et al., 2016). We show that monetary policy that relaxes financial constraints of weak banks (i.e. those with low Tier-1 ratios and high NPLs) affects their lending behavior.

Jiménez et al. (2014) and Ioannidou et al. (2015) find that a reduction in interest rates results in excessive risk-taking by poorly capitalized banks consistent with a search-for-yield. Dell'Ariccia et al. (2017) find evidence consistent with theories on risk-shifting behavior of better capitalized banks when interest rates decrease. In our setting, monetary policy only indirectly affects the bank lending channel as a response by banks to changes in the capital structure of less risky firms. We find that, while banks with large exposure to CSPP-eligible firms start to lend more to riskier firms, these firms do not appear to be "zombie" firms, as they have high interest coverage ratios, are profitable and banks are compensated through higher loan spreads for higher borrower risk. In other words, our results suggest more risk-taking but no obvious reckless lending behavior, and the results are consistent with the literature on internal capital markets arguing that constrained firms shift resources to respond to the most attractive investment opportunity (Stein, 1997; Scharfstein and Stein, 2000).

There is a nascent literature on the real economic effects of LSAPs (Di Maggio, Kermani, and Palmer, 2016; Kandrac and Schlusche, 2017; Chakraborty, Goldstein, and MacKinlay, 2017; Rodnyanski and Darmouni, 2017). These researchers investigate asset purchases that directly 
affect banks' portfolios. Our approach is different. We find that corporate bond purchases affect NFCs directly and have an indirect, yet important, effect on bank lending. Koijen et al. (2018) show that sovereign bond yields decline following LSAPs, echoing the results in other studies investigating the effects of portfolio rebalancing on asset prices (Altavilla, Carboni, and Motto, 2016; Andrade et al., 2016). However, these studies do not examine the purchases of corporate bonds or consider the effects on corporate financial and investment policies, which is the focus of our paper.

Abidi and Ixart (2018) and Arce, Gimeno, and Mayordomo (2017) study the effect of the CSPP on bond yields and issuance volume for Spanish firms. We investigate more broadly the effects of the CSPP across the euro area and show the program's effect on eligible firms' debt capital structure decisions. Importantly, we investigate real economic effects, such as firm investment activity. We also contribute to the debate about the differential effect of purchasing specific assets by central banks.

Finally, our paper connects to the literature documenting the role of bank shocks on credit supply (Kashyap and Stein, 2000; Ivashina and Scharfstein, 2010; Puri, Rocholl, and Steffen, 2011; Schnabl, 2011) and how it affects firm activities (Leary, 2009; Chava and Purnanandam, 2011; Peek and Rosengren, 2015). Becker and Ivashina (2014) quantify bank loan supply over time by studying a firm's substitution between bank loans and bonds. We find that central bank purchases affect firms' demands for bonds relative to loan financing, which affects loan supply to firms without access to public capital markets.

\section{Institutional framework and methodology}

\subsection{Institutional framework}

As a response to the global financial crisis (2007-2009) and the European sovereign debt 
crisis, which started in Fall 2010, the ECB introduced a series of unconventional policy measures including liquidity provision to the banking sector through long-term refinancing operations and an asset purchase program (APP). The ECB introduced the APP in 2009 to purchase limited amounts of covered bonds; asset-backed securities were added in 2014. In January 2015, the ECB expanded the size of the APP from $€ 10$ to $€ 60$ billion per month, also including large-scale purchases of sovereign bonds in a public sector purchase programme (PSPP).

Because of the anemic recovery of the European economy and realized inflation below the ECB's target inflation rate of 2\%, the ECB further expanded its APP on March 10, 2016, and announced it would increase its purchase volume to $€ 80$ billion per month. More importantly, it announced that the APP would now include corporate bonds as a new asset class. The composition of assets in the overall APP purchase amount (capped at $€ 80$ billion per month) is at the discretion of the ECB. ${ }^{4}$ Further details on the CSPP were announced on April 21, 2016, and the CSPP updates were first implemented on June 8, 2016, with a minimum duration until March 2017. The APP has been extended since then, but the ECB announced on June 14, 2018 that it will reduce the purchase volume to $€ 15$ billion per month during the September to December 2018 period and that it will end net purchases under the APP as of December 31, 2018. Even beyond this point, however, maturing sovereign and corporate bonds can be reinvested at the discretion of the ECB.

The ECB introduced several eligibility criteria regarding the type of corporate bonds it can purchase under the CSPP. Importantly, the issuer has to be a NFC incorporated in the eurozone. Moreover, the issue has to have an IG rating from at least one of the four rating agencies: S\&P,

\footnotetext{
${ }^{4}$ The ECB's corporate bond purchases reflect the universe of outstanding corporate bonds (e.g. across industries), while sovereign bond purchases follow strict rules and have to be proportional to the capital key (euro area national central banks' individual shares in the ECB's capital), which rules out potential endogeneity issues that corporate or sovereign bond purchases influence each other.
} 
Moody's, Fitch Ratings, or DBRS. ${ }^{5}$ During the June 2016 to December 2017 period, the ECB purchased more than $€ 130$ billion eligible corporate bonds from eurozone firms. While its rules permit purchases both in the primary and secondary market, about $85 \%$ of the bonds it purchased had already traded in secondary markets.

\subsection{Methodology}

\subsubsection{The effects of central bank corporate bond purchases on eligible firms}

To examine the capital structure channel of monetary policy, we first investigate how the introduction of the CSPP affects firms' demand for bank versus bond debt. As the ECB's decisions about which bonds to purchase are potentially endogenous, we condition our analysis on the eligibility for purchase before the announcement of the program. Specifically, we conduct an ITT analysis in which the purchase of bonds is instrumented with the eligibility before the announcement of the program. The ITT effect measures the average effect of corporate bond purchases on the group of eligible firms, which differs from the treatment-on-the-treated (TOT) effect, i.e. the average impact on the firm whose bonds the ECB decided to purchase. The ITT is our preferred measure for the causal effect of the CSPP on firms' financing decisions given the likely spillovers on bonds that are eligible but have not been purchased, for example due to a shift in demand by investors through portfolios rebalancing and a corresponding reduction in the term premium (Stein, 2012; Koijen et al., 2016). ${ }^{6}$ In the rest of the paper, we thus report the ITT effects.

We implement our identification strategy using a DiD setup, where the treatment group is composed of all CSPP-eligible firms. These are firms incorporated in eurozone countries with an

\footnotetext{
${ }^{5}$ Other criteria include a minimum maturity of bonds of six months, a maximum maturity of 31 years, and a yield-tomaturity larger than the ECB's deposit facility rate. The principal can be reinvested upon maturity (ECB, 2018).

${ }^{6}$ The correlation between our ex-ante treatment, i.e., eligibility, definition and the ex-post purchase decisions by the ECB (an indicator variable that is one if the ECB bought at least one bond of firm $i$ under the CSPP during our sample period) is high (0.86).
} 
IG rating. The control group consists of non-eligible eurozone firms, i.e. non-rated or non-IG-rated public firms. This identification is not perfect as the treatment is not randomly assigned but is instead placed on a potentially endogenous variable (i.e. IG rating). We discuss this and how it affects our point estimates in detail in Subsection 5.2.2.

To account for systematic differences between treatment and control firms, we remove control firms that do not have public debt outstanding in any of the four quarters prior to the CSPP announcement as they may not have had bond market access. We saturate our model using a large set of controls and fixed effects to account for remaining systematic differences between treatment and control firms. We run the following standard DiD specification:

$$
\text { Leverage }_{i t}=a_{i}+a_{k t}+a_{c t}+\beta \text { Post x Treated } \text { Tit }+\theta^{\prime} Y_{i t-1}+\varepsilon_{i t}
$$

We use different proxies for Leverage as we are specifically interested in the effect of the CSPP on debt capital structure composition (Bond Debt/Assets, Term Loans/Assets, Revolving Credit/Assets, Bank Debt/Bond Debt). Post is a dummy variable that equals one in the period after the CSPP announcement, i.e. Q2 2016 to Q1 2017, and zero otherwise. Treated is a dummy variable that equals one if the firm is part of the treatment sample, and zero otherwise. $Y$ is a set of firm characteristics that determine a firm's demand for debt: we include firm size, measured as the natural logarithm of total assets; firm profitability, which we measure as EBITDA over total assets; tangible assets of the firm; and the market-to-book ratio (e.g. Faulkender and Petersen, 2006; Sufi, 2009). All control variables enter our regression with a one-quarter lag. We further include firm fixed effects $\left(a_{i}\right)$, industry x quarter fixed effects $\left(a_{k t}\right)$, and country x quarter fixed effects $\left(a_{c t}\right)$. These fixed effects account for shocks for a narrowly defined industry group (two-digit SIC codes) in each quarter, as well as shocks at the country-quarter level that might affect a firm's choice of bond debt. A limited number of observations within clusters restricts the use of industry $\mathrm{x}$ country 
$\mathrm{x}$ quarter fixed effects. $\beta$ shows the effect of the CSPP on a firm's debt capital structure. We cluster standard errors at the firm level, i.e. the level of treatment (Bertrand, Duflo, and Mullainathan, 2004). We use a model similar to Eq. (1) when analyzing the effect of the ECB's corporate bond purchases on the investment decisions of eligible firms.

\subsubsection{Central bank corporate bond purchases and the bank lending channel of monetary policy}

We next analyze how the ECB's corporate bond purchases affect the bank lending channel. The capital structure channel of monetary policy predicts that corporate bond purchases crowd out demand for bank loans by eligible firms, which in turn redirects banks' lending capacity to firms without access to public capital markets or whose bonds are non-eligible for purchase. We identify this mechanism by exploiting the fact that banks are differentially affected by the CSPP and examine whether banks with large exposure to eligible firms increase the loan supply to noneligible firms relative to banks with a small exposure. We construct a proxy, IG Share, to determine to what extent banks are affected by the CSPP. In particular, IG Share is the share of (nonfinancial) IG borrowers in bank $j$ 's term loan portfolio before the introduction of the CSPP and before the start of our sample period. The proxy is defined as:

$$
\text { IG Share } \mathrm{j}_{\mathrm{j}}=\frac{\sum \$ \text { Term loans to eurozone IG firms by bank } \mathrm{j}}{\sum \$ \text { Term loans to all European firms by bank } \mathrm{j}}
$$

which is estimated over the 2010 to 2014 , i.e. pre-CSPP, period. This proxy captures the extent to which banks are exposed to firms whose bonds have become eligible under the CSPP. We focus on term loans, as credit lines and bonds are not close substitutes (Berg et al., 2017). A bank loan pair is only considered if the bank is lead arranger. ${ }^{7}$ In some specifications, we use an indicator

\footnotetext{
${ }^{7}$ We exclude non-European banks and small banks, i.e. banks with a total (term loan) lending volume of less than $\$ 1,000$ million over the five-year period from 2010 to 2014 . We further require that key loan characteristics are available (issue date, maturity, amount, and loan spread). We identify lead arrangers following Sufi (2007) and Ivashina (2009). We equally split the loan amount when there are multiple lead arrangers in a loan facility, as the coverage on lender shares in our loan-level data is limited. We aggregate bank subsidiaries under the ultimate parent.
} 
variable for banks with an above-median share of eligible borrowers in their portfolio (High IG Share) instead of the continuous $I G$ Share to ease the interpretation of results.

Using loan-level information, we next construct a panel at the bank-firm level. The sample is collapsed to a pre-CSPP period and a post-CSPP period, i.e. the panel contains two observations per bank-firm pair. The pre-CSPP period is comprised of loans issued between January 2015 and March 10, 2016. The post-CSPP period contains loans issued between March 10, 2016 and March 31, 2017. We exclude bank-firm pairs with zero loan volume in the pre- and post-CSPP periods. We exploit the fact that some firms have relationships with more than one bank and use a withinfirm estimator to disentangle loan demand from loan supply (Khwaja and Mian, 2008). That is, we estimate within-firm variation across banks that are differentially affected by the CSPP. In particular, we estimate the following regression model:

$$
\operatorname{pr}(\text { Loan })_{\mathrm{ijt}}=\mathrm{a}_{\mathrm{it}}+\mathrm{a}_{\mathrm{ij}}+\beta \text { Post }_{\mathrm{t}} * \text { IG Share }_{\mathrm{j}}+\varepsilon_{\mathrm{ijt}} \text {, }
$$

where $\operatorname{pr}($ Loan) is the probability that firm $i$ receives a loan from bank $j$ (as lead arranger) in period t. A positive $\beta$ implies that firms have a higher likelihood of obtaining a loan after the CSPP announcement when borrowing from a bank with a higher IG Share after controlling for loan demand via firm $x$ period fixed effects $\left(a_{i t}\right) ; a_{i j}$ are firm $x$ bank fixed effects. In alternative specifications, we use the loan amount as a dependent variable and estimate the model specifically for private firms. These firms are typically more reliant on bank debt as an external financing source and are thus not directly affected by the program (e.g. Acharya et al., 2017). We cluster standard errors at the bank level in all specifications.

Finally, we examine loan supply and investment effects at the firm-year level, as balance sheet information for non-eligible (in particular, private) firms is only available on an annual level. Analogous to Eq. (2), we determine the extent to which banks' relationships with firm $i$ are affected 
by the CSPP. If a firm has an active lending relationship with more than one bank, we include the average $I G$ Share across all lenders. ${ }^{8}$

We estimate the following model:

$$
z_{i t}=a_{i}+a_{k t}+a_{c t}+\beta \text { Post }_{t} * I G \text { Share }_{i}+\theta^{\prime} Y_{i t-1}+\varepsilon_{i t} .
$$

Post equals one for 2016, and zero otherwise. $z$ is a proxy for firms' loan supply across banks or a proxy for firms' investment activity. The regressions include firm-level controls, $Y$, to control for the heterogeneity in firm characteristics [ $\ln ($ Total Assets), Profitability, Tangibility, Leverage]. We also include firm fixed effects $\left(a_{i}\right)$, industry x year fixed effects $\left(a_{k t}\right)$, and country $\mathrm{x}$ year fixed effects $\left(\mathrm{a}_{\mathrm{ct}}\right)$ to control for demand effects at the industry or country level. We cluster standard errors at the firm level. The sample spans the 2015 to 2016 period.

\section{Data and descriptive statistics}

\subsection{Sample selection}

\subsubsection{Capital IQ sample}

We obtain quarterly data from Compustat Global for all public firms that are incorporated in eurozone countries. We supplement the data set with debt structure and credit rating information from S\&P's Capital IQ, as well as additional issuer credit ratings (Moody's, Fitch, and DBRS) from Bloomberg. The sample period is from Q1 2015 to Q1 2017 and thus contains four quarters before and four quarters after the CSPP announcement. We exclude financial firms (SIC codes 6000-6999) and firm quarters with missing key financial information. This leaves us with 2,281 unique eurozone firms. We also exclude firms that do not have public debt outstanding in the pre-

\footnotetext{
${ }^{8}$ We define that firm $i$ has a lending relationship with bank $j$ if the firm obtained at least one loan from bank $j$ (as lead arranger) during the 2010 to 2014, i.e. pre-CSPP, period. We focus on bank lending relationships before the start of our sample period to rule out the idea that the results are affected by an endogenous decision of firms to switch banks. We restrict the sample to eurozone NFCs with an active bank relationship in the pre-CSPP period.
} 
CSPP period, which reduces our sample to 890 unique firms; 135 of these firms (the treatment group) have an IG rating. These 135 firms represent only about $15 \%$ of the total sample but account for over half of the total revenue of the sample in Q4 2015. We define the credit rating as a firm fixed effect. In particular, we use the last available rating information before the CSPP announcement to ensure that the treatment status is not affected by the event (e.g. firms may choose to obtain a rating or reduce risk to achieve IG status post-CSPP).

Importantly, Capital IQ decomposes total debt into seven distinct, mutually exclusive types: commercial paper, (drawn) credit lines, term loans, senior bonds and notes, subordinated bonds and notes, capital leases, and other debt. This enables us to separately analyze the CSPP's effect on the different debt components, in particular on bank versus bond financing. We define bond debt as commercial paper, senior bonds and notes, and subordinated bonds and notes. Bank debt is defined as (drawn) credit lines and term loans. Total debt is defined as the sum of all individual debt components. Some firms provide financial statements only semi-annually. For these firms, we fill in missing values using the previous quarter. Finally, we obtain bond-level information from Dealogic. All variables are defined in Appendix A.2.

\subsubsection{DealScan-Amadeus sample}

To analyze the effect of the ECB's corporate bond purchases on non-eligible firms, we obtain loan-level information from the DealScan database. We restrict the sample to loans to NFCs in the eurozone. For annual firm-level balance sheet information, we use BvD's Amadeus database as it has been used in prior research on European firms (e.g. Heider, Saidi, and Schepens, 2017) and covers both public and private companies. Using this data, we construct a DealScan-Amadeus matched data set. 


\subsection{Descriptive statistics}

Table 1 reports the summary statistics for the Capital IQ sample over the period before the announcement of the CSPP, distinguishing between treatment and control firms. All variables are winsorized at the 1st and 99th percentile. Descriptive statistics for the overall sample are provided in the Online Appendix of this paper.

The average total debt-to-assets ratio for treatment firms is $30 \%$, consisting mainly of bond debt: the average bond debt-to-assets ratio is $20 \%$, while the average term loans-to-assets ratio is $6 \%$. The average total debt-to-assets ratio for the control group is $36 \%$. Control firms, on average, have a lower fraction of bond debt compared to treatment firms (15\% vs. $20 \%)$ and a higher share of term loans (14\% vs. $6 \%)$. Treatment firms are, on average, larger compared to control firms [ $\ln$ (Assets) are 9.9 and 6.2, respectively]. Further, treatment firms have a higher fraction of tangible to total assets $(0.29$ vs. 0.26$)$. Treatment firms are also, on average, more profitable and are more likely to repurchase shares compared to control group firms. We address the potential concern that observable differences between treatment and control firms affect our results in Subsection 5.3. All other firm characteristics do not differ significantly between groups.

[Table 1 here]

\section{Central bank corporate bond purchases and debt capital structure of eligible firms}

\subsection{Bond issuance spreads}

We first analyze bond issuance yields around the introduction of the CSPP. Motivated by theories that emphasize the importance of LSAPs on asset prices (e.g. Vayanos and Vila, 2009, Greenwood, Hanson, and Stein, 2010; Krishnamurthy and Vissing-Jorgensen, 2013), we hypothesize that the CSPP announcement reduces yields of eligible versus non-eligible corporate bonds. Using bond issuance data from Dealogic, we construct yield spreads subtracting the 
maturity-matched swap rate from the yield-to-maturity rate, similar to Dick-Nielsen, Feldhütter, and Lando (2012). We obtain swap rates from Datastream.

\section{[Figure 1 here]}

In Fig. 1, we plot the yield spreads at issuance in basis points for eligible (Panel A) and non-eligible bonds (Panel B) for each individual issue. We also plot the quarterly average of the yield spreads for the respective categories. As in prior studies, we distinguish between AAA-A and BBB-rated bonds to separate high- and low-quality IG bonds (Longstaff et al., 2005; Krishnamurthy and Vissing-Jorgensen, 2011; Rauh and Sufi, 2010). For example, Krishnamurthy and Vissing-Jorgensen (2011) consider BBB bonds a natural threshold when examining safety effects, i.e., they argue that bonds above this threshold may potentially also be affected by a clientele-driven demand for safety, while BBB bonds are closer to non-investment grade securities. We do not find a significant change for the average bond issuance spread for AAA-A-rated bonds; however, there is a substantial drop in yield issuance spreads for BBB-rated bonds (144 to 104 bps). The results in Panel B of Fig. 1 suggest that firms issuing non-eligible, i.e. high-yield or nonrated, bonds do not benefit from the CSPP.

Our results are unlikely to be driven by a portfolio rebalancing of institutional investors due to the ECB's PSPP. First, we would not observe a differential yield spread effect for eligible relative to non-eligible bonds only after the announcement of the CSPP. Moreover, we observe a significant effect only for BBB-rated corporate bonds, even though the closest substitute for sovereign bonds are AAA-rated corporate bonds (Badoer and James, 2016). We also conduct a placebo test and compute a DiD estimate around the announcement of the PSPP in January 2015 (unreported). We do not find a differential yield spread effect for eligible relative to non-eligible firms. Our findings are consistent with Krishnamurthy and Vissing-Jorgensen (2011), who 
likewise find no spillovers from U.S. Treasury bond purchases to corporate bond yields. ${ }^{9}$

\subsection{Debt capital structure}

\subsubsection{Baseline results}

We first analyze the impact of the ECB's corporate bond purchases on firms' capital structure decisions following the CSPP announcement in Q1 2016. We employ the DiD design described in Subsection 3.2.1 and estimate Eq. (1) using ordinary least squares regressions. The results are presented in Table 2.

\section{[Table 2 here]}

In Panel A of Table 2, we report the results using Bond Debt/Assets as the dependent variable. We start with a base specification without any fixed effects or control variables [column (1)]. We then saturate the model with firm and quarter fixed effects [column (2)], country x quarter fixed effects [column (3)], and industry x quarter fixed effects [column (4)]. The most saturated model shows that the bond debt-to-assets ratio increased post-CSPP announcement by 2 pp for treatment relative to control group firms and relative to the pre-CSPP period. This effect is not only statistically significant, but it is also economically meaningful: given an average share of bond debt-to-assets of $16 \%$ in our sample, the CSPP announcement increases bond debt-to-assets by about $13 \%$ relative to the unconditional mean. The inclusion of (potentially endogenous) control variables only has a negligible effect on the Treated $x$ Post coefficient. ${ }^{10}$

In Panel B of Table 2, we investigate other debt capital structure components. We find that eligible firms reduce their term loans-to-assets ratio after the CSPP announcement by 1 pp relative

\footnotetext{
${ }^{9}$ Panel A of Fig. 1 also reveals that the overall issuance activity increased following the CSPP announcement. While 49 eligible bonds were issued, on average, in each quarter before the announcement, this number increased to an average of 69 eligible bonds after the announcement. In contrast, we do not observe an increase in the number of noneligible bond issuances after the announcement (Panel B). Overall, these stylized facts suggest very limited direct spillovers of the central bank purchases into the sample of non-eligible firms (our control group).

${ }^{10}$ We relay other tests to an Online Appendix that features specifications without control variables, different dependent variables, as well as specifications based on actual bond issuances.
} 
to control firms and relative to the pre-CSPP period [columns (5) to (6)]. This is economically significant, given an average share of term loans-to-assets of $13.2 \%$ in the sample. In contrast, we find no evidence that eligible firms significantly reduce their credit line debt after the CSPP announcement [columns (7) and (8)]. Columns (9) and (10) report the results using Total Debt/Assets as the dependent variable: eligible firms do not increase their leverage relative to noneligible firms after the CSPP announcement. Columns (11) and (12) show the results when we use the bank-to-bond debt ratio as the dependent variable. We find that eligible firms decrease their bank-to-bond debt ratio by about $5 \mathrm{pp}$ following the CSPP announcement relative to non-eligible firms. Overall, we find that firms respond to the reduction in corporate bond yields and increase bond financing after the CSPP announcement in Q1 2016.

\subsubsection{Endogeneity of treatment}

A possible concern might be that our treatment is not randomly assigned but is based on a potentially endogenous variable, i.e. a firm's IG rating. That is, there might be (unobservable) factors that differentially affect treated and control firms and that are correlated with a firm's debt structure decision. More precisely, there might be unobservable bond demand that coincides with the introduction of the CSPP, i.e. factors that would have affected treated (relative to control) firms even in the absence of the program. This might introduce a bias in the coefficient of our treatment and its direction depends on the covariance of our treatment variable with the unobservable factor (Roberts and Whited, 2013). Economic theory does not provide clear guidance as to the direction of this bias. While unobservable changes in bond demand may correlate positively with rating quality (suggesting that the bias is positive, i.e. we would overestimate the CSPP effect), IG-rated firms might have fewer investment opportunities due to already low interest rates or low growth prospects (suggesting that the bias is negative and we would underestimate the CSPP effect). 
Khwaja and Mian (2008) argue that the direction of the covariance can be measured comparing the biased coefficient of the endogenous variable with the unbiased coefficient. In our setting, the unbiased coefficient is unobservable. However, it might be possible to infer the likely direction of the bias by comparing the coefficient of our endogenous variable (Treated $x$ Post) across different specifications. In Panel A of Table 2, we report regression results of a specification without any controls or fixed effects in column (1) and add controls as well as fixed effects and report the results from the most saturated model in column (4). The coefficient is positive and economically and statistically significant across all specifications. Importantly, it increases once we control for possible factors that affect bond demand through fixed effects. These results suggest that the covariance is negative and that our estimates are likely to be in the lower bounds of the true effect of the CSPP. We cannot control for any remaining unobservable (and time-varying) demand factors, which might be positively correlated with the treatment. However, the effect of the unobservable factors has to be about twice as large as the effect from the observable factors to reduce the coefficient to zero. Moreover, the adjusted $\mathrm{R}^{2}$ already increases from 0.01 in column (1) to 0.85 in column (4), i.e. the effect of the unobservable factors per (remaining) $R^{2}$ has to be even larger (Altonji, Elder, and Taber, 2005; Oster, 2016). We provide further tests to rule out that our results are driven by factors unrelated to the CSPP in Section 5.3.

\subsubsection{Cross-sectional differences in credit ratings among eligible firms}

Our earlier analysis shows a significant drop in yield spreads of BBB-rated bonds but not for AAA-A-rated bonds after the CSPP announcement. To test whether the substitution of term loans with bonds is more concentrated among BBB-rated firms than AAA-A-rated firms, we include the interaction terms $A A A-A$ Rating $x$ Post and BBB Rating $x$ Post as treatment and run the same specification as in Eq. (1). The results are reported in Table 3. 
[Table 3 here]

We find that the increase in bond debt is larger for BBB-rated firms following the CSPP announcement [column (1)]. In particular, BBB-rated firms increase their bond debt-to-assets ratio by $2.3 \mathrm{pp}$ post-CSPP relative to the control group, while AAA-A-rated firms experience a $1.4 \mathrm{pp}$ increase in bond debt; the difference between groups, however, is not statistically significant. The results reported in column (2) suggest that BBB-rated firms significantly decrease their term loansto-assets ratio post-CSPP, whereas AAA-A-rated firms do not change their percentage of term loan financing post-CSPP. This indicates that in particular, BBB-rated firms respond to the CSPP and substitute bank debt with bond debt. ${ }^{11}$

Consistent with Table 2, we find no evidence that AAA-A or BBB-rated firms change their percentage of credit line financing in their capital structure post-CSPP [column (3)]. Column (4) shows that the overall leverage ratio does not increase significantly for BBB-rated firms postCSPP announcement (i.e. these firms only adjust their debt composition). AAA-A-rated firms, in contrast, increase their total debt post-CSPP (+ $1.8 \mathrm{pp})$. Column (5) indicates that BBB-rated firms decrease their bank-to-bond debt ratio by about $7 \mathrm{pp}$, while we find no effect for AAA-A-rated firms. Overall, our results are consistent with the first prediction of the capital structure channel of monetary policy: eligible firms shift from bank to bond financing as a result of the central bank corporate bond purchase program.

\subsection{Discussion of results}

\subsubsection{Parallel trend assumption and placebo test}

The ECB could intensify an already ongoing trend in an increase in bonds relative to loan

\footnotetext{
${ }^{11}$ We find that the ECB also concentrated purchases on BBB-rated as well as A- rated corporate bonds. Our results are qualitatively similar if we split our sample into "AAA to A" and "A- to BBB-" rated firms. Overall, these results are consistent with the conjecture that firms that have been targeted to a larger extent respond more heavily.
} 
financing (Adrian, Colla, and Shin, 2013). A causal interpretation of the effect of the CSPP relies on the parallel trend of eligible and non-eligible firms before its announcement with respect to their financing decisions. We thus perform a parametric test of the parallel trend assumption and include a series of dummy variables in our regression Eq. (1) to differentiate the quarter-by-quarter effects of the CSPP on leverage. We control for the same firm-level controls $(Y)$ and fixed effects as before.

[Figure 2 here]

Fig. 2 illustrates that there are no significantly different pre-trends in bond issuance activity of treated versus control firms before the CSPP announcement in Q1 2016. All coefficients are statistically insignificant at conventional levels in the period prior to the CSPP announcement. Following the announcement, the bond debt-to-assets ratio starts to increase visibly for treatment relative to control firms, and the effect is statistically significant. In other words, even if there was an increase in use of bond relative to loan financing before the announcement of the CSPP, this trend was not different for eligible compared to non-eligible firms.

The ECB also announced an expansion of its PSPP in March 2016. A potential concern might be that our results are driven by the increase in the ECB's government bond purchases through the same channels as described in the context of corporate bond prices above. We conduct a placebo test to address this concern and analyze changes in the bond debt financing of CSPPeligible firms around the introduction of the PSPP in January 2015. We restrict the sample period to Q1 2014 to Q4 2015 and Post now equals one after the PSPP announcement, and zero otherwise.

[Table 4 here]

The results are reported in column (1) of Table 4. We find no evidence that CSPP-eligible firms reacted to the PSPP announcement in 2015, giving us confidence that our results are not 
driven by the PSPP expansion in Q1 2016, which was substantially smaller in size compared to the program initiation in January 2015. Our results are also consistent with Krishnamurthy and Vissing-Jorgensen (2013), who show that U.S. Federal Reserve purchases of Treasuries significantly raised Treasury prices but had limited spillover effects to private sector bond yields.

\subsubsection{Borrower risk and monitoring}

Another concern is related to our treatment group definition, which is along the IG boundary. Bond issuances for IG relative to non-IG firms could increase because the former are less risky and need less monitoring (as in e.g. Diamond, 1991; Chemmanur and Fulghieri, 1994). We use control variables and fixed effects to control for firm risk in our regression specification and have further controlled for possible demand shocks at a narrowly defined industry-quarter and country-quarter level. In this subsection, we provide further examination of firm risk.

If borrower risk is driving our results, we would expect to observe a gradual decline in bond debt-to-assets ratios across the rating categories. If, however, treatment firms increase bond debt relative to non-eligible firms due to the CSPP, we would expect to see a discontinuity at the IG (eligibility) boundary. We augment our specification and interact Post with indicator variables for each of the following categories: AAA-A, BBB, BB, B, and unrated. The regression results are reported in column (2). Tracing the IG rating boundary, we find that the coefficient drops significantly when we move from a BBB to a BB-rated (or B-rated) firm and the difference between the $\mathrm{BBB}$ and the $\mathrm{BB}$ coefficient is highly statistically significant. In contrast, within the group of eligible firms, the difference between AAA-A and BBB-rated firms is again not significant. As expected, we do not find any effect within the control group. ${ }^{12}$

\footnotetext{
12 Another explanation for the increase in bond debt and the decrease in bank debt could be a reduction in loan supply (Becker and Ivashina, 2015). If banks reduced their supply of loans particularly for BBB-rated firms, these firms might respond and shift into bond financing. In our hypothesis, we suggest the opposite: if the decline in loans was supply-
} 


\subsubsection{Matched control group}

The descriptive statistics reported in Table 1 indicate that treatment and control firms differ for some dimensions, such as size and profitability, before the CSPP. For robustness, we run our regression specification using a matched control group. We use a nearest neighbor propensity score matching to assign a control firm that is closest in terms of size, profitability, bond debt, and bank debt to each treatment firm in the pre-CSPP period. We allow for a difference in the probability of receiving treatment between matched subjects of $1 \%$ and report descriptive statistics regarding the quality of the match in the Online Appendix. We confirm that there are no remaining differences in the variables used to match treatment and control group firms over the pre-CSPP period. The results for the matched sample, which is smaller as there are no comparable control firms for all treatment firms in terms of size, are reported in column (3). The effect is economically even stronger compared to our results reported in Table 2, indicating that the effects are not driven by observable differences between treatment and control firms.

To rule out that our results are driven by any remaining differences in credit quality between treatment and control firms, we further construct an alternative control group that is comprised of European IG-rated firms that are incorporated outside the eurozone. The results in column (4) show that eligible firms increase their bond debt-to-assets ratio relative to IG firms incorporated outside the eurozone.

\subsubsection{Effect on loan rates}

If yields go down, eligible firms should look financially more solid. Why do banks not internalize this decrease in default risk and adjust their loan spreads downwards to prevent firms

driven, we would not expect to see an increase in lending by banks to other firms once some customers have shifted from bank loans to bonds. However, this is exactly what we find. 
from switching? ${ }^{13}$ The CSPP may not only affect the default risk component of bond spreads but may also have an impact on other factors, such as market liquidity. De Pooter et al. (2018) and Eser and Schwaab (2016) show that sovereign bond liquidity premia significantly declined in response to ECB large-scale sovereign debt purchases. ${ }^{14}$ We test this in the context of the CSPP using data from Dealogic and Bloomberg to compute the high-low bid-ask spread estimator from Corwin and Schultz (2012), which is supposed to be among the most widely used daily liquidity measures in the context of over-the-counter bond markets (Schestag et al., 2015). We find that the average daily high-low estimator of CSPP-eligible bonds decreased by about $11 \mathrm{pp}$ more compared to non-eligible bonds in the six-month window around the ECB's CSPP announcement in March 2016. Bank loans, in contrast, are usually illiquid, particularly in Europe due to less developed secondary markets for loans. Thus, it is unlikely that banks are able to fully match the resulting spread decline.

\subsection{Eligible firms' investment decisions}

How do firms respond to a change in their cost of capital? We follow prior literature (e.g. Sufi, 2009) and investigate the impact of the CSPP on real sector activity related to our eligible firms. More specifically, we use asset growth, changes in cash and working capital, as well as capital expenditures as proxies for real outcome. We also add acquisitions and payout as additional left-hand side variables. The results are reported in Table 5.

[Table 5 here]

\footnotetext{
${ }^{13}$ Given the lack of data on secondary market loan prices in the eurozone and given that we only observe very few new loan issues by CSPP-eligible firms post-CSPP announcement, we cannot provide a clean estimate for the CSPP effect on loan spreads. However, if banks reduce loan spreads in response to the CSPP, this should bias our estimates downwards, if anything. That is, eligible firms likely would have substituted private with public debt to an even larger extent in absence of spread reductions in the loan market.

${ }^{14}$ Preliminary evidence suggests that the CSPP similarly increased corporate bond market liquidity. For instance, the ECB argues that "bid-ask spreads have tightened considerably since the start of the CSPP, suggesting that the program has been supportive of liquidity conditions" (ECB, 2018).
} 
Overall, we find no evidence that the CSPP has a first-order effect on investment activities of eligible firms. The coefficient of our treatment variable is insignificant in all specifications with respect to BBB-rated firms. Consistent with an increase in leverage, AAA-A rated firms experience an increase in asset growth and somewhat increase their M\&A related activities. This is consistent with e.g. Stein (2012), who argues that firms naturally take advantage of lower cost of debt capital, but that their hurdle rate for new investments does not necessarily change at the same time. Acharya and Plantin (2018) show that the hurdle might even increase as investments and financial activities (such as share buybacks) compete for funds. Our results are thus more consistent with theories emphasizing the limited impact of loose monetary policy on investment rates of firms that are not financially constrained.

\section{ECB corporate bond purchases and the bank lending channel of monetary policy}

How do the ECB's corporate bond purchases affect the bank lending channel? The capital structure channel of monetary policy predicts that central banks' purchases of corporate bonds can strengthen the banks' lending channel because it changes the financing incentives for large firms with access to public debt.

\subsection{Bank lending to non-eligible firms}

\subsubsection{Baseline results}

To determine to what extent banks are affected through a shift of eligible firms from term loans into bonds after the announcement of the CSPP, we construct a proxy, IG Share, as defined in Eq. (2). In particular, IG Share is the share of (non-financial) IG borrowers in a bank's term loan portfolio, measured over the 2010 to 2014 period.

We run the base specification from Eq. (3) to investigate whether non-eligible firms have a higher likelihood of receiving a loan after the announcement of the CSPP when they have 
borrowed from a bank with a higher $I G$ Share. The results in Table 6 show that this is not the case [column (1)]. The coefficient is economically small and statistically insignificant.

[Table 6 here]

Next, we report the effects for private relative to public firms as private firms might be more financially constrained (Acharya et al., 2017). The results, reported in columns (2) to (6), indicate that private firms are more likely to obtain a loan when borrowing from a bank with a higher IG Share after the CSPP announcement relative to public firms. Column (5), for instance, shows that private firms are $7 \mathrm{pp}$ more likely to obtain a loan post-CSPP when borrowing from a High IG Share bank relative to public firms.

Finally, we restrict the sample to private firms to ensure that our results are not driven by a relative reduction of lending to public versus private firms and find consistent results [columns (7) to (8)].

It is unlikely that our results can be explained by an increase in the net worth of banks due to the ECB's sovereign bond purchases, which increases their capacity to lend. First, sovereign bond exposure is not different between both types of banks, as we show below in Table 7. Second, we run the same specification for the Q1 2014 to Q4 2015 period, where the post-treatment period starts after the PSPP announcement in Q1 2015. The substantially larger magnitude of the sovereign bond purchases initiated with the PSPP as compared to the increase in purchases in April 2016 helps us to separate the effect of sovereign bond vis-à-vis corporate bond purchases on lending. We do not find a statistically significant increase in bank lending to private firms during this period [columns (9) to (10)].

Finally, one might argue that the ECB's targeted long-term refinancing operations (TLTRO-II), announced in March 2016 and implemented in June 2016, can explain an increase in 
lending unrelated to the CSPP. While funding conditions of that program are linked to banks' net lending, the majority of the TLTRO-II borrowing is used to refinance existing TLTRO-I borrowings (ECB, 2017). Importantly, to explain our results, borrowings need to be correlated with banks' IG Share. We collect bank and country level TLTRO-II borrowing and show in Table 7 below that the fraction of banks with (disclosed) TLTRO-II borrowings is similar across banks with a high and low IG Share. We then interact High IG Share x Post with a TLTRO-II Bank indicator and the percentage of the aggregated country level borrowing, TLTRO-II Country, in models (11) and (12) of Table 6, respectively. In unreported tests, we use a dummy variable that equals one for countries with the highest absolute TLTRO-II borrowings (Italy, Spain, France, and Germany), and zero otherwise. Overall, our previous results remain unchanged.

\subsubsection{Lender characteristics}

A possible concern could be heterogeneity across banks with High IG Share or Low IG Share, which could affect the matching between banks and firms and thus banks' lending decisions. We report descriptive statistics of bank characteristics (obtained from SNL Financial) that reflect commonly used measures related to capital adequacy, asset quality, profitability, and liquidity in Table 7.

[Table 7 here]

We find that High IG Share banks (above-median IG Share) and Low IG Share banks are similar in terms of observable characteristics across these dimensions. Moreover, the groups are similar in terms of their sovereign debt exposure, both in absolute amounts and in their exposure to domestic relative to total sovereign debt exposure ("home bias"). In other words, both groups of banks are similar in terms of observable characteristics that could drive their lending decisions. ${ }^{15}$

\footnotetext{
${ }^{15}$ While High IG Share are larger than Low IG Share banks in terms of total assets, the difference is statistically insignificant (p-value of 12\%). Size differences can be expected as IG firms are typically larger and require larger
} 


\subsubsection{Bank capital constraints}

What are the mechanisms through which the CSPP increases lending to private firms? The capital structure channel of monetary policy predicts that ex-ante constrained banks are more affected by a shift from term loans to bonds by eligible firms. We measure constraints using banks' regulatory capital (i.e. Tier 1 ratio) and NPL to total loans ratio (cf. Blattner, Farinha, and Rebelo, 2018). We use banks' end of 2015 capital ratios to reduce endogeneity concerns. Banks are constrained if they are in the lowest Tier 1 ratio or in the highest NPL ratio tercile. We report the results in Table 8 .

\section{[Table 8 here]}

Consistent with our theoretical framework, we find that private firms have a higher likelihood of obtaining a loan post-CSPP if banks were ex-ante more constrained, i.e. have either low Tier 1 ratios [column (1)] or have a high fraction of NPLs [column (3)]. ${ }^{16}$

\subsection{Bank loan portfolio risk}

In this subsection, we investigate whether banks' loan portfolios become riskier postCSPP. A shift in high-quality firms' demand from loans to bonds might increase the percentage of lower-quality firms in banks' portfolios. Also, if banks redirect capital to new, possibly lower NPV loans, this might further increase overall loan portfolio risk. We test this using the change in the

\footnotetext{
loans. Our results, however, are robust to matching banks on size. Details are provided in the Online Appendix, which also provides additional descriptive statistics that show that High IG Share banks and Low IG Share banks behaved similarly in key dimensions over the years leading up to the CSPP announcement, such as lending to retail customers or corporates (among others). We also provide the names of the top-five and bottom-five banks ranked by IG Share in the Online Appendix.

${ }^{16}$ A simple back-of-the-envelope calculation indicates that capital savings can be substantial. Assuming that banks use an internal-ratings-based approach to calculate risk-weighted assets (RWA), a loss-given-default rate of 30\%, a (remaining) loan maturity of three years, and a one-year default rate of $0.26 \%$ (Moody's migration matrix), this translates into RWA of $39.14 \%$. For example, the default rate of a borrower with a 3-notch higher (worse) rating is $0.06 \%(1.4 \%)$, which translates into RWA of $17.11 \%$ and $77.61 \%$, respectively. In other words, for each $€ 1$ loan to a BBB-rated firm, a bank can either make a $€ 2$ loan to a 3-notch higher-rated company or, alternatively, a $€ 0.5$ loan to a 3-notch lower-rated company, holding Tier 1 capital constant.
} 
distribution of loan spreads of High IG Share and Low IG Share banks in the post- versus preCSPP period. As most firms in our sample are private and unrated, we use the loan spread as a proxy for loan risk (Pierret and Steri, 2017). This is commonly done in the literature using the allin-drawn spread (AISD), the spread above the risk-free interest rate such as LIBOR.

[Figure 3 here]

First, we plot the kernel density of the AISD distribution for High IG Share banks in Panel A of Fig. 3 using a Gaussian kernel. We show a density shift from low AISD to high AISD loans. For example, the median AISD of the portfolios of High IG Share banks is 75 bps higher in the post-CSPP period, an increase of about one-third. We do not find the same shift in the spread distribution of Low IG Share banks (Panel B of Fig. 3). Second, we calculate the DiD estimate of the median spread of High IG Share and Low IG Share banks in the post- versus pre-CSPP period. Our point estimate for this difference is $50 \mathrm{bps}$, which is statistically and economically significant. See the Online Appendix of this paper for details. Taken together, our results suggest an increase in bank portfolio risk following the introduction of the CSPP. ${ }^{17}$

\subsection{Financing and investment decisions of non-eligible firms}

\subsubsection{Financing decisions of non-eligible firms: firm-level effects}

Our earlier results point to a causal effect of the CSPP through a capital structure channel on the supply of loans to private firms. To assess the pass-through of the program to the real economy, we ask who receives new loans and how funds are used. In a first step, we examine aggregate loan supply effects at the firm-year level. Given that the spillover effects of the CSPP

\footnotetext{
${ }^{17}$ We collect data on loan amendments that might reflect a covenant waiver or a general tightening of loan terms as a result of poor performance after loan origination. Loans issued by High IG Share banks post-CSPP have a somewhat higher likelihood to be amended relative to those loans issued by Low IG Share banks. This is consistent with the interpretation that the increased ex-ante loan portfolio risk is associated with a higher post-issue fraction of poorly performing borrowers.
} 
are concentrated in the group of private firms, we restrict the main sample to this group and analyze effects for public firms as robustness tests. In particular, we estimate Eq. (4) using a dummy variable that equals one if firm $i$ obtains a loan in year $t$, and zero otherwise, as the dependent variable.

[Table 9 here]

We report the results in Panel A of Table $9 .{ }^{18}$ Column (1) shows that the likelihood that a private firm issues a loan after the announcement of the CSPP is about 8.8 pp higher if the firm borrows from High IG Share banks. Given that the unconditional likelihood of issuing a loan in our panel is about $20 \%$, this corresponds to about a $44 \%$ increase in the probability of obtaining a loan. We report descriptive statistics for the DealScan-Amadeus linked sample in the Online Appendix of this paper. In column (2), the dependent variable is the (log) loan amount. The loan volume obtained by private firms is about $46 \%$ higher in the post-CSPP period if the firm borrows from a High IG Share bank. Finally, we re-run the specification from column (1) using public firms, i.e. less financially constrained firms with access to public capital markets. The result, reported in column (3), indicates that these firms are less likely to obtain a loan from an affected bank post-CSPP, which is consistent with our earlier results that CSPP-eligible borrowers switch from bank to bond financing after the implementation of the program.

The results so far suggest that banks redirect lending to private firms following the CSPP announcement. However, is this capital allocated efficiently in the broader economy? We split the sample into low-quality and high-quality firms based on characteristics measured before the CSPP, i.e. at the end of 2015. Low-quality (high-quality) firms are defined as firms with a below (above)

\footnotetext{
${ }^{18}$ We only report the High IG Share results for brevity and ease of interpretation, i.e. we use a dummy variable that equals one if the firm is borrowing from banks with an above-median share of IG borrowers. However, our results are similar when we use $I G$ Share as a continuous variable.
} 
median profitability or interest coverage ratio. The results are reported in Panel B of Table 9. We find no evidence that banks increase lending to low-performing firms. In contrast, the effects appear to be stronger for firms with a high profitability [column (5)] and high interest coverage ratio [column (7)]. Again, our results are consistent with spillovers of the CSPP to non-eligible firms. Banks with a high percentage of CSPP-eligible borrowers in their portfolio increase lending to (profitable) private firms after the announcement of the program.

\subsubsection{Investment decisions of non-eligible firms}

How does the increase in lending to private firms affect their investment decisions? Previous research highlights negative consequences of loan supply reductions. Conversely, an increase in loan supply driven by an expansive monetary policy might positively transmit into the real economy. To examine the behavior of private firms post-CSPP, we estimate Eq. (4) using firms' asset growth and CapEx as dependent variables. The results are reported in Table 10.

[Table 10 here]

We start by analyzing firms' asset growth. Consistent with an increase in loan supply and hence leverage, we find that firms that borrow from High IG Share banks have higher asset growth rates following the CSPP announcement [column (1)]. Further, column (2) indicates that these firms also experience an increase in CapEx. In particular, the CapEx-to lagged fixed asset ratio is about $3.8 \mathrm{pp}$ higher relative to the pre-CSPP period and relative to firms that borrow from banks with a low fraction of IG borrowers. This effect is economically significant given an unconditional mean of 5.9\%. Overall, our results are consistent with the conjecture that the increase in lending to private firms alleviates financial constraints with positive real effects.

To address remaining concerns that our results may be driven by a general strengthening of the economy that differentially affects borrowers from High IG Share versus Low IG Share 
banks, we construct a new variable, High GDP Growth, which is one if a country has abovemedian GDP growth. GDP growth is defined as the percentage change in (average) quarterly GDP over the post-CSPP-period (Q2 2016 - Q1 2017) relative to the pre-CSPP-period (Q1 2015 - Q1 2016). We introduce a triple interaction term, High IG Share x Post $x$ High GDP Growth, and run the same model as before. The results are reported in columns (3) and (4). The coefficients on the interaction terms are insignificant, suggesting that the increase in growth and investments is not driven by a strengthening of the economy. ${ }^{19}$

\section{Conclusion}

We study the transmission channels from central banks' quantitative easing programs via the banking sector when central banks start purchasing corporate bonds. Motivated by existing theories, we hypothesize that the announcement of ECB purchases reduces bond yields of firms whose bonds are eligible for these purchases. These firms substitute bank term loans with bond debt, which relaxes banks' lending constraints. Banks can use their balance sheet capacity to provide credit to firms, which might previously have been constrained. We call this a "capital structure channel" of monetary policy. We test this channel in the context of the ECB's CSPP and find consistent evidence.

Our results raise several interesting questions. We find that the credit reallocation causes banks to increase risk-taking in corporate credit. However, our analysis does not allow us to make broader statements regarding its implications for financial stability. Hoshi (2001), Hoshi and Kashyap (2004), and Balloch (2018) analyze a period of deregulation in Japan, which

\footnotetext{
${ }^{19} \mathrm{We}$ also show graphically that these firms do not behave differently along dimensions such as leverage, asset growth, and investments in the pre-CSPP period. These results are reported in an Online Appendix. Finally, we run the same tests introducing a triple interaction term High IG Share x Post x GIIPS but do not find any differential real effect in GIIPS countries (Greece, Ireland, Italy, Portugal or Spain, i.e. those countries with subdued economic recovery following the sovereign debt crisis). We do not report these results for reasons of space.
} 
fundamentally changed corporate financing patterns during the 1980s. An easing of bond issuance rules elicited a rapid shift from bank to bond financing, particularly by large firms. Banks, in turn, increased lending to small companies, real estate firms, and foreign companies, which increased bank exposure to riskier parts of the economy. Japanese banks suffered losses with the collapse of stock and land prices at the beginning of the 1990s and a sharp deceleration in growth in the Japanese economy. In the context of the CSPP, it is thus important to understand how banks change their lending behavior when firms switch from loan to bond financing.

Moreover, we have not addressed questions with respect to the effectiveness of different central bank programs or the sequence of central bank interventions. While we highlight channels of how purchases of corporate bonds can affect the real economy, other asset classes could potentially be purchased with similar effects. We leave these questions for future research. 


\section{References}

Abidi, N., Ixart M.-F., 2018. Who benefits from the ECB's corporate sector purchase programme? A difference-in-discontinuities approach. Unpublished working paper. European Central Bank.

Adrian, T., Colla, P., Shin, H., 2013. Which financial frictions? Parsing the evidence from the financial crisis of 2007 to 2009. In: Acemoglu, D., Parker, J., Woodford, M. (Eds.), NBER Macroeconomics Annual 2012. University of Chicago Press, Chicago, pp. 159214.

Acharya, V., Eisert, T., Eufinger, C., Hirsch, C., 2017. Whatever it takes: the real effects of unconventional monetary policy. Unpublished working paper. NYU.

Acharya, V., Plantin, G., 2018. Monetary easing, investment and financial instability. Unpublished working paper. Science Po.

Altavilla, C., Carboni, G., Motto, R., 2016. Asset purchase programmes and financial markets: lessons from the euro area. Unpublished working paper. European Central Bank.

Andrade, P., Breckenfelder, J., de Fiore, F., Karadi, P., Tristani, O., 2016. The ECB's asset purchase programme: an early assessment. Unpublished working paper. European Central Bank.

Arce, O., Gimeno, R., Mayordomo, S., 2017. Making room for the needy: the credit-reallocation Effects of the ECB's corporate QE. Unpublished working paper. Banco de España.

Badoer, D., James, C., 2016. The determinants of long-term corporate debt issuances. Journal of Finance 71, 457-492.

Balloch, C., 2018. Inflows and spillovers: tracing the impact of bond market liberalization. Unpublished working paper. Columbia University.

Becker, B., Ivashina, V., 2014. Cyclicality of credit supply: firm level evidence. Journal of Monetary Economics 62, 76-93.

Becker, B., Ivashina, V., 2015. Reaching for yield in the bond market. Journal of Finance 70, 1863-1902.

Berg, T., Saunders, A., Steffen, S., Streitz, D., 2017. Mind the gap: the difference between U.S. and European loan rates. Review of Financial Studies 30, 948-987.

Bertrand, M., Duflo, E., Mullainathan, S., 2004. How much should we trust differences-indifferences estimates? Quarterly Journal of Economics 119, 249-275.

Blattner, L., Farinha, L., Rebelo, F., 2018. When losses turn into loans: the cost of undercapitalized banks. Unpublished working paper. Harvard Business School.

Brunnermeier, M., Sannikov, Y., 2015. The I theory of money. Unpublished working paper. Princeton University. 
Campello, M., 2002. Internal capital markets in financial conglomerates: evidence from small bank responses to monetary policy. Journal of Finance 57, 2773-2805.

Chakraborty, I., Goldstein, I., MacKinlay, A., 2017. Monetary stimulus and bank lending. Unpublished working paper. University of Pennsylvania.

Chava, S., Purnanandam, A., 2011. The effect of banking crisis on bank-dependent borrowers. Journal of Financial Economics 99, 116-135.

Chemmanur, T., Fulghieri, P., 1994. Reputation, renegotiation, and the choice between bank loans and publicly traded debt. Review of Financial Studies 7, 475-506.

Corwin, S. A., Schultz, P., 2012. A simple way to estimate bid-ask spreads from daily high and low prices. Journal of Finance 672, 719-760.

Dell'Ariccia, G., Laeven, L.U.C., Suarez, G.A., 2017. Bank leverage and monetary policy's risktaking channel: evidence from the United States. Journal of Finance 72, 613-654.

Diamond, D., 1991. Monitoring and reputation: the choice between bank loans and directly placed debt. Journal of Political Economy 99, 689-721.

Di Maggio, M., Kermani, A., Palmer, C., 2016. How quantitative easing works: evidence on the refinancing channel. Unpublished working paper. National Bureau of Economic Research.

Dick-Nielsen, J., Feldhütter, P., Lando, D., 2012. Corporate liquidity before and after the onset of the subprime crisis. Journal of Financial Economics 103, 471-492.

ECB, 2018. ECB Economic Bulletin, Issue 3, 2018.

ECB, 2017. ECB Economic Bulletin, Issue 3, 2017.

Eser, F., Schwaab, B., 2016. Evaluating the impact of unconventional monetary policy measures: empirical evidence from the ECB' s securities markets programme. Journal of Financial Economics 119, 147-167.

Faulkender, M., Petersen, M., 2006. Does the source of capital affect capital structure? Review of Financial Studies 19, 45-79.

Gambacorta, L., Mistrulli, P., 2004. Does bank capital affect lending behavior? Journal of Financial Intermediation 13, 436-457.

Gomez, M., Landier, A., Sraer, D., Thesmar, D., 2016. Banks' exposure to interest rate risk and the transmission of monetary policy. Unpublished working paper. National Bureau of Economic Research.

Greenwood, R., Hanson, S., Stein, J., 2010. A gap-filling theory of corporate debt maturity choice. Journal of Finance 65, 993-1028.

Hanson, S.G., Stein, J.C., 2015. Monetary policy and long-term real rates. Journal of Financial Economics 115, 429-448. 
Heider, F., Saidi, F., Schepens, G., 2017. Life below zero: bank lending under negative policy rates. Unpublished working paper. European Central Bank.

Holmstrom, B, J. Tirole, 1997. Financial intermediation, loanable funds, and the real sector. Quarterly Journal of Economics 112, 664-691.

Hoshi, T., 2001. What happened to Japanese banks? Monetary and Economic Studies 19, 1-29.

Hoshi, T., Kashyap, A., 2004. Corporate financing and governance in Japan: the road to the future, volume 1 . The MIT Press.

Ioannidou, V., Ongena, S., Peydró, J.-L., 2015. Monetary policy, risk-taking, and pricing: evidence from a quasi-natural experiment. Review of Finance 19, 95-144.

Ivashina, V., 2009. Asymmetric information effects on loan spreads. Journal of Financial Economics 92, 300-319.

Ivashina, V., Scharfstein, D., 2010. Bank lending during the financial crisis of 2008. Journal of Financial Economics 97, 319-338.

Jiménez, G., Ongena, S., Peydro, J.-L., Saurina, J., 2014. Hazardous times for monetary policy: what do twenty-three million bank loans say about the effects of monetary policy on credit risk-taking? Econometrica 82, 463-505.

Kandrac, J., Schlusche, B., 2017. Quantitative easing and bank risk taking: evidence from lending. Unpublished working paper. Board of Governors of the Federal Reserve System.

Kashyap, A., Stein, J., 1994. Monetary policy and bank lending. In: Mankiw, N. (Ed.), Monetary Policy. University of Chicago Press, Chicago, pp. 221-256.

Kashyap, A., Stein, J., 1995. The impact of monetary policy on bank balance sheets. CarnegieRochester Conference Series on Public Policy 42, pp. 151-195.

Kashyap, A., Stein, J., 2000. What do a million observations on banks say about the transmission of monetary policy? American Economic Review 90, 407-428.

Khwaja, A., Mian, A., 2008. Tracing the impact of bank liquidity shocks: evidence from an emerging market. American Economic Review 98, 1413-1442.

Kishan, R., Opiela, T., 2000. Bank size, bank capital, and the bank lending channel. Journal of Money, Credit and Banking 32, 121-141.

Koijen, R., Koulischer, F., Nguyen, B., Yogo, M., 2018. Quantitative easing in the euro area: the dynamics of risk exposures and the impact on asset prices. Unpublished working paper. University of Chicago.

Krishnamurthy, A., Vissing-Jorgensen, A., 2011. The effects of quantitative easing on interest rates: channels and implications for policy. Brookings Papers on Economic Activity.

Krishnamurthy, A., Vissing-Jorgensen, A., 2013. The ins and outs of LSAPs. Unpublished working paper. Stanford Graduate School of Business. 
Leary, M., 2009. Bank loan supply, lender choice, and corporate capital structure. Journal of Finance 64, 1143-1185.

Longstaff, F.A., Mithal, S., Neis, E., 2005. Corporate yield spreads: default risk or liquidity? New evidence from the credit default swap market. Journal of Finance 60, 2213-2253.

Oster, E., 2016. Unobservable selection and coefficient stability: theory and evidence. Journal of Business \& Economic Statistics, 1-18.

Peek, J., Rosengren, E., 2015. The role of banks in the transmission of monetary policy. In: Berger, A., Molyneaux, P., Wilson, J. (Eds.), The Oxford Handbook of Banking, pp. 453473.

Pierret, D., Steri, R., 2017. Stressed banks. Unpublished working paper. HEC Lausanne.

Puri, M., Rocholl, J., Steffen, S., 2011. Global retail lending in the aftermath of the US financial crisis: distinguishing between demand and supply effects. Journal of Financial Economics 100, 556-578.

Rauh, J.D., Sufi, A., 2010. Capital structure and debt structure. Review of Financial Studies 23, $4242-4280$.

Roberts, M. R., Whited, T. M., 2013. Endogeneity in corporate finance. Handbook of the Economics of Finance 2, 493-572.

Rodnyanski, A., Darmouni, O., 2017. The effects of quantitative easing on bank lending behavior. Review of Financial Studies 11, 3858-3887.

Schestag, R., Schuster, P., Uhrig-Homburg, M., 2016. Measuring liquidity in bond markets. Review of Financial Studies 29, 1170-1219.

Schnabl, P., 2011. The international transmission of bank liquidity shocks: evidence from an emerging market. Journal of Finance 67, 897-932.

Stein, J., 1997. Internal capital markets and the competition for corporate resources. Journal of Finance 52, 111-133.

Stein, J., 2012. Remarks at the third Boston University/Boston Fed conference on macro-finance linkages. Boston, Massachusetts, November 30, 2012.

Stein, J., Scharfstein, D., 2000. The dark side of internal capital markets: divisional rent-seeking and inefficient investment. Journal of Finance 55, 2537-2564.

Sufi, A., 2007. Information asymmetry and financing arrangements: evidence from syndicated loans. Journal of Finance 62, 629-668.

Sufi, A., 2009. The real effects of debt certification: evidence from the introduction of bank loan ratings. Review of Financial Studies 22, 1659-1691.

Vayanos, D., Vila, J.-L., 2009. A preferred-habitat model of the term structure of interest rates. Unpublished working paper. National Bureau of Economic Research. 


\section{Figure 1}

\section{Corporate bond spreads around the CSPP announcement}

This figure plots the yield spreads for bonds issued from Q1 2015 to Q1 2017, separately for CSPP-eligible bonds, i.e. IG-rated bonds, and non-CSPP-eligible bonds. Further reported is the mid-quarter average. The gray line indicates the CSPP announcement on March 10, 2016.

\section{Panel A. Yield spreads for AAA-A and BBB-rated bonds}

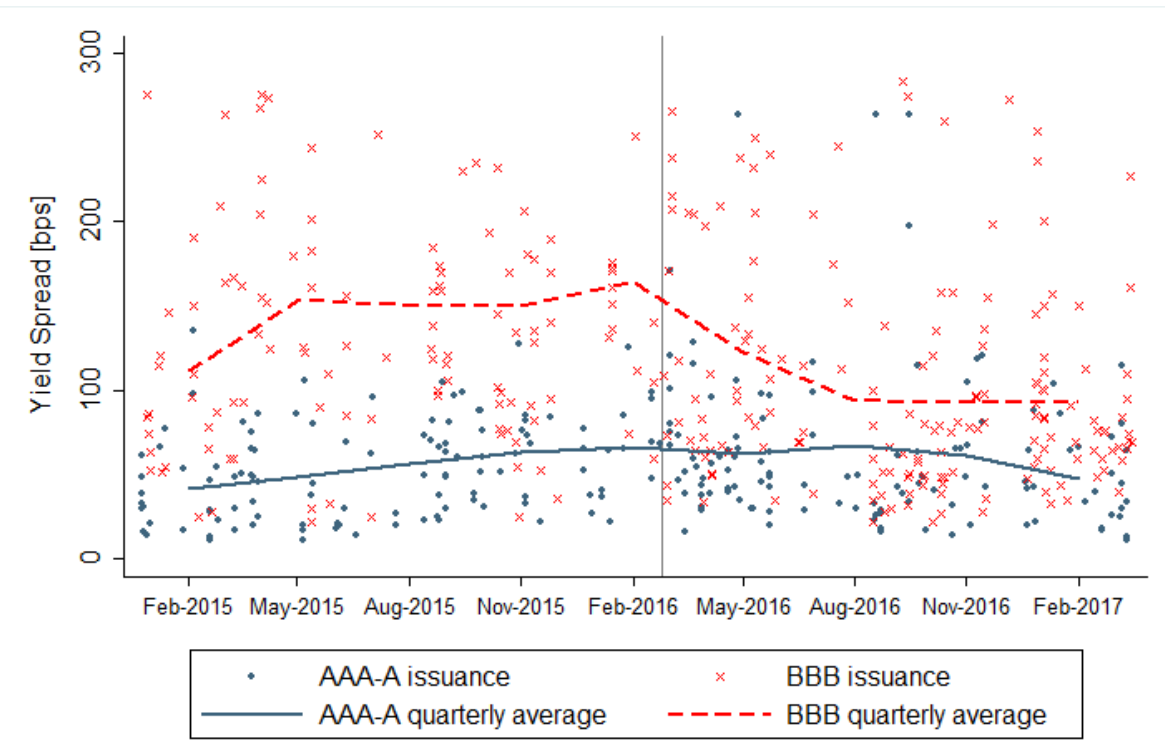

\section{Panel B. Yield spreads for non-CSPP-eligible bonds}

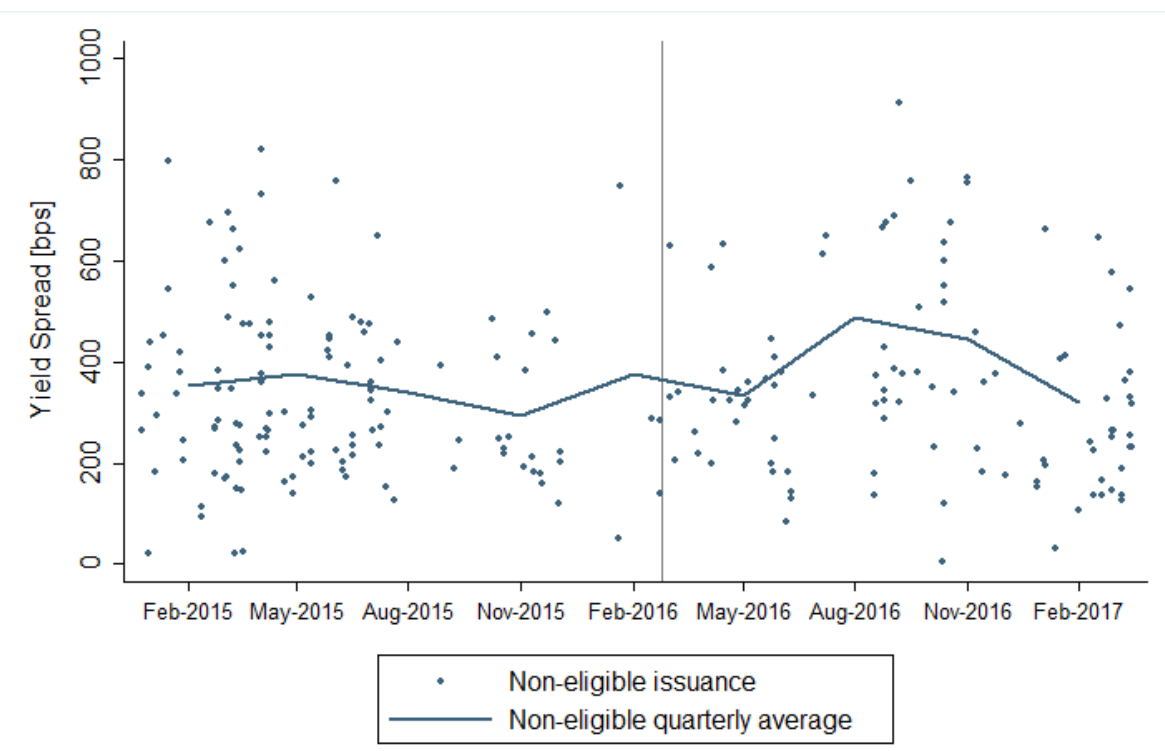




\section{Figure 2}

\section{Identification: parallel trend assumption}

This figure plots the impact of central bank corporate bond purchases on bond financing of eurozone firms. We consider a 13-quarter window, spanning from nine quarters before the CSPP announcement until four quarters thereafter. The dashed lines represent $95 \%$ confidence intervals, adjusted for firm-level clustering. Specifically, we report estimated coefficients from the following regression:

$$
\begin{aligned}
& \text { Bond Debt/Assets } s_{i t}=a_{i}+a_{c t}+\beta_{1} \text { Treated }_{i} * Q 12014+\beta_{2} \text { Treated }_{i} * Q 22014+\cdots \\
& +\beta_{12} \text { Treated }_{i} * Q 12017+\gamma^{\prime} Y_{i t-1}+\varepsilon_{i t} .
\end{aligned}
$$

Treated $*$ Quarter equals one for treatment firms, i.e. eurozone IG firms, in the respective quarter, and zero otherwise. We exclude Q1 2016, thus estimating the dynamic effect of central bank corporate bond purchases on bond financing relative to the CSPP announcement quarter. We control for firm fixed effects and country x quarter fixed effects. Further included are firm-level controls, $Y$, to control for the heterogeneity in firm characteristics (cf. Table 2). The control group comprises non-IG-rated eurozone firms that have public debt outstanding in the four quarters prior to the announcement.

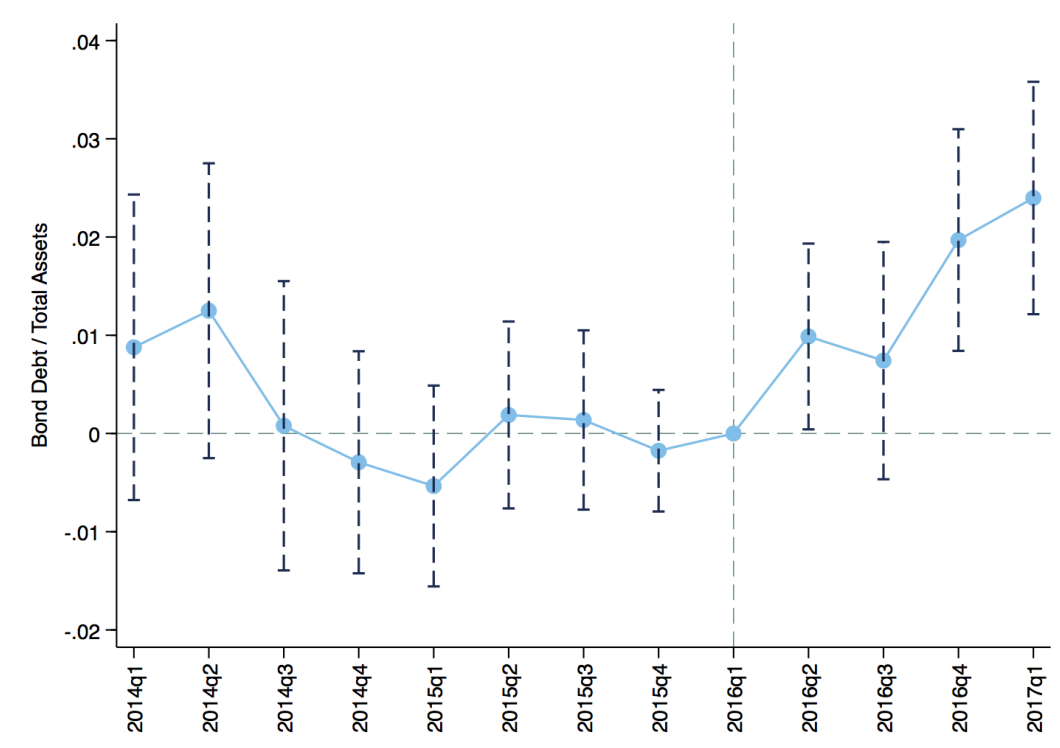




\section{Figure 3}

\section{Banks' syndicated loan portfolio risk: pre-CSPP versus post-CSPP}

This figure shows the kernel density plots for the all-in-drawn spread (in basis points) on loans issued pre-CSPP (Q1 2015 to Q1 2016) versus post-CSPP (Q2 2016 to Q1 2017). We separately plot the distribution for loans in which the lead arrangers are "High IG Share banks", i.e. banks with an above-median share of IG borrowers in the term loan portfolio, measured over the 2010 to 2014 period, and "Low IG Share banks" (below-median IG borrower share). The kernel estimation method is Gaussian, and the bandwidth is chosen such that the width minimizes the mean integrated squared error.

\section{Panel A. Loan spread distribution for High IG Share banks: pre-CSPP versus post-CSPP}

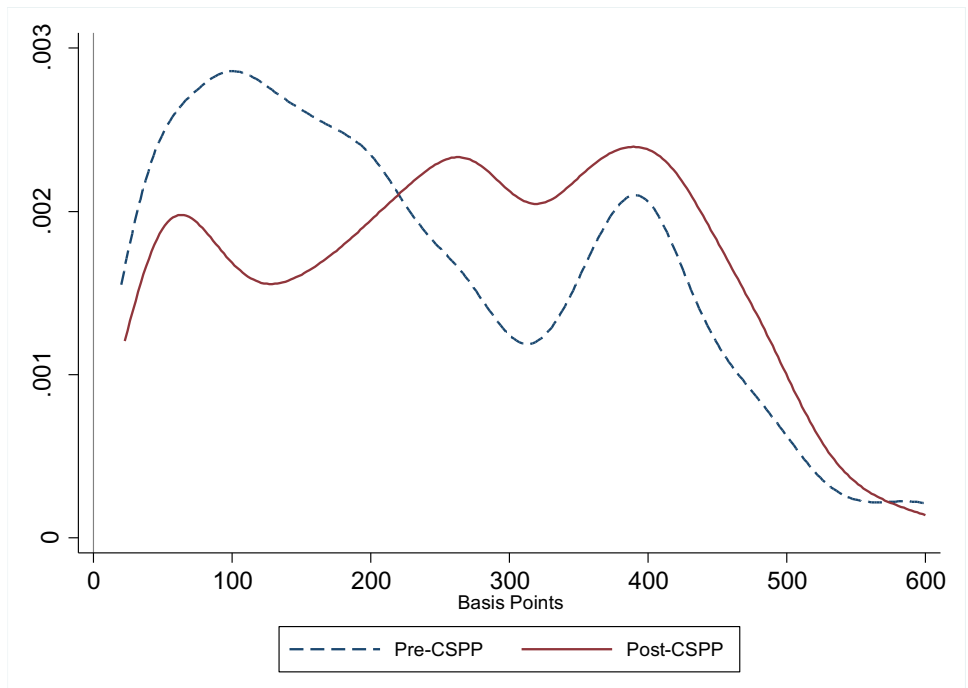

Panel B. Loan spread distribution for Low IG Share banks: pre-CSPP versus post-CSPP

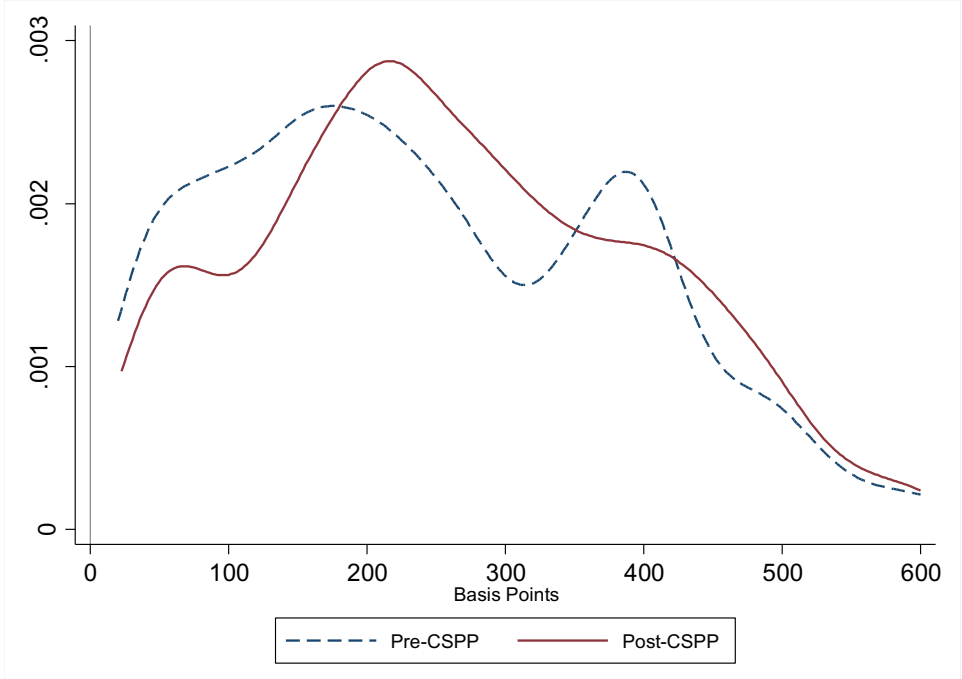


Table 1

\section{Descriptives}

This table reports summary statistics for the key variables in our sample over the period before CSPP implementation, i.e. Q1 2015 to Q1 2016. Treatment firms are eurozone IG firms. The control group comprises non-IG-rated eurozone firms with public debt. All variables are defined in Appendix A.2.

TREATED

\begin{tabular}{|c|c|c|c|c|c|c|c|c|}
\hline & Mean & Median & Std. D. & $\mathrm{N}$ & Mean & Median & Std. D. & $\mathrm{N}$ \\
\hline Total Debt/Assets & 0.301 & 0.280 & 0.141 & 647 & 0.362 & 0.315 & 0.242 & 3,507 \\
\hline Bond Debt/Assets & 0.196 & 0.193 & 0.106 & 647 & 0.152 & 0.116 & 0.147 & 3,511 \\
\hline Term Loans/Assets & 0.062 & 0.038 & 0.084 & 647 & 0.145 & 0.090 & 0.171 & 3,510 \\
\hline Revolving Credit/Assets & 0.009 & 0.000 & 0.018 & 647 & 0.030 & 0.000 & 0.066 & 3,511 \\
\hline $\ln$ (Assets) & 9.857 & 9.783 & 1.177 & 647 & 6.165 & 6.273 & 2.221 & 3,511 \\
\hline Profitability & 0.027 & 0.026 & 0.014 & 639 & 0.014 & 0.019 & 0.034 & 3,445 \\
\hline Tangibility & 0.290 & 0.266 & 0.202 & 644 & 0.262 & 0.218 & 0.220 & 3,481 \\
\hline $\mathrm{MtB}$ & 1.456 & 1.334 & 0.512 & 617 & 1.527 & 1.178 & 1.490 & 3,368 \\
\hline Asset Growth & 0.001 & 0.000 & 0.043 & 638 & 0.008 & 0.000 & 0.085 & 3,471 \\
\hline$\Delta$ Cash/Lagged Assets & 0.000 & 0.000 & 0.037 & 638 & 0.002 & 0.000 & 0.057 & 3,463 \\
\hline$\Delta$ WorkCap/Lagged Assets & -0.002 & 0.000 & 0.038 & 637 & 0.003 & 0.000 & 0.089 & 3,465 \\
\hline CapEx/Lagged Assets & 0.011 & 0.008 & 0.008 & 602 & 0.010 & 0.007 & 0.012 & 3,135 \\
\hline Acq/Lagged Assets & 0.004 & 0.000 & 0.013 & 637 & 0.003 & 0.000 & 0.010 & 3,471 \\
\hline Share Rep. & 0.036 & 0.000 & 0.185 & 647 & 0.008 & 0.000 & 0.087 & 3,511 \\
\hline
\end{tabular}


Table 2

\section{Effect of central bank corporate bond purchases on debt financing of eligible firms}

This table reports results from the estimation of a pooled panel regression analyzing the effect of central bank corporate bond purchases on bond financing, bank financing, and total leverage. The dependent variable in columns 1-4 is Bond Debt/Assets, i.e. the sum of senior bonds, subordinated bonds, and commercial paper scaled by total assets. The dependent variable in columns 5-6 is Term Loans/Assets, i.e. term loans scaled by total assets. The dependent variable in columns 7-8 is Revolving Credit/Assets, i.e. revolving credit scaled by total assets. The dependent variable in columns $9-10$ is Total Debt/Assets, i.e. total debt scaled by total assets. The dependent variable in columns 11-12 is the ratio of Bank Debt to Bond Debt. Treated equals one for eurozone IG firms, and zero for the control group (non-IG-rated eurozone firms with public debt). Post equals one after the CSPP announcement, i.e. after Q1 2016, and zero otherwise. The sample period is Q1 2015 to Q1 2017. The regressions include firm-level controls to control for the heterogeneity in firm characteristics [ $\ln$ (Total Assets) ${ }_{\text {it-1 }}$, Profitability $_{\mathrm{it}-1}$, Tangibility $\left.{ }_{\mathrm{it}-1}\right]$, when indicated. All variables are defined in Appendix A.2. The regressions further include firm fixed effects, quarter fixed effects, industry x quarter fixed effects, and country x quarter fixed effects, when indicated. We report $\mathrm{t}$-values based on standard errors clustered at the firm level in parentheses. ***, $* *, *$ denote significance at the 1,5 and $10 \%$ level, respectively.

\section{Panel A. Effect on bond debt}

\begin{tabular}{l} 
Variable: \\
\hline Treated x Post \\
Treated \\
Post \\
2-digit SIC x Quarter FE \\
Country x Quarter FE \\
Quarter FE \\
Firm FE \\
Controls \\
Observations \\
\hline
\end{tabular}

$$
\text { (1) }
$$

\section{(2)}

Bond Debt

Beb

$0.0109^{* *}$

(2.14)

$0.0411^{* * *}$

(4.01)

$-0.0027$

$(-0.84)$

(omitted)

(omitted)

/ Assets
$0.0116^{* *}$
$(2.44)$

No No

No No

No Yes

No Yes

No No
(3)

Bond Debt

/ Assets

$0.0160^{* * *}$

(3.21)

(omitted)

(omitted)

6,611
(4)

Bond Debt

/ Assets

$0.0201^{* * *}$

(3.61)

(omitted)

(omitted)

Panel B. Effect on other debt components and total debt

(5)

Term Loans

Variable:

Treated x Post

/ Assets

$-0.0102 * *$

$(-2.39)$

2-digit SIC x Quarter FE

Country x Quarter FE

Firm FE

Controls

Observations

Total Deb

Variable:

Treated $\mathrm{x}$ Post

/ Assets

0.0087

(1.42)

No
Yes
Yes
Yes
6.609

(6)

Term Loans

/ Assets

$-0.0097^{*}$

(10)
Total Debt

\begin{tabular}{c} 
No \\
Yes \\
Yes \\
Yes \\
6,601 \\
\hline
\end{tabular}

2-digit SIC x Quarter FE

Country x Quarter FE

Firm FE

Controls

Observations
6,601
(7)

\begin{tabular}{cc} 
No & Yes \\
Yes & Yes \\
No & No \\
Yes & Yes \\
Yes & Yes \\
6,611 & 6,569 \\
\hline
\end{tabular}

$(-1.66)$

\section{Yes}

Yes

Yes

Yes

6,567

Revolving Credit/

Assets

0.0033

(1.47)

No Yes

Yes Yes

Yes Yes

Yes Yes

$6,611 \quad 6,569$

(11)

Bank Debt

(12)

Bank Debt

/ Bond Debt

$0.0418^{* * *}$

/ Bond Debt

0.0109

(1.61)

$(-3.04)$

$(-2.71)$

No
Yes
Yes
Yes
6,601

Yes

Yes

Yes

Yes

6,559 
Table 3

\section{Effect of central bank corporate bond purchases on debt financing of eligible firms: credit quality} effect

This table reports results from the estimation of a pooled panel regression analyzing the effect of central bank corporate bond purchases on bond financing, bank financing, and total leverage. The dependent variable in column 1 is Bond Debt/Assets, i.e. the sum of senior bonds, subordinated bonds, and commercial paper scaled by total assets. The dependent variable in column 2 is Term Loans/Assets, i.e. term loans scaled by total assets. The dependent variable in column 3 is Revolving Credit/Assets, i.e. revolving credit scaled by total assets. The dependent variable in column 4 is Total Debt/Assets, i.e. total debt scaled by total assets. The dependent variable in column 5 is the ratio of Bank Debt to Bond Debt. AAA-A Rating equals one for eurozone firms rated AAA-A, and zero otherwise. $B B B$ Rating equals one for eurozone firms rated $\mathrm{BBB}$, and zero otherwise. Post equals one after the CSPP announcement, i.e. after Q1 2016, and zero otherwise. The sample period is Q1 2015 to Q1 2017. The regressions include firm-level controls to control for the heterogeneity in firm characteristics (cf. Table 2). All variables are defined in Appendix A.2. The regressions further include firm fixed effects, industry x quarter fixed effects, and country x quarter fixed effects. We report t-values based on standard errors clustered at the firm level in parentheses. $* * *, * * *$ denote significance at the 1,5 and $10 \%$ level, respectively.

Variable:

AAA-A Rating x Post

BBB Rating x Post

2-digit SIC x Quarter FE
Country x Quarter FE
Firm FE
Controls
Observations

AAA-A = BBB? (p-value)
(1)

(2)

Bond Debt

/ Assets

$0.0141^{*}$
$(1.74)$

$0.0227 * * *$

(3.58)

Yes

Yes

Yes

Yes

6,569

0.351
Revolving Credit/Assets

/ Assets

0.0046

$(0.62)$

$-0.0160 * *$

$(-2.51)$

Yes

Yes

Yes

Yes

6,567

(3)

0.0044

(1.22)

0.0019

(0.75)

(4)

Total Debt $/$ Assets

0.0180
$(1.80)$

$(1.80)$
0.0077

(1.09)

Yes

Yes

Yes

Yes

6,569

0.400

(5)

Bank Debt / Bond Debt / Bond D (0.36) $-0.0731 * * *$ $(-3.66)$

Yes Yes

Yes Yes

Yes Yes

Yes Yes

$6,559 \quad 6,490$

$6,559-6,490$




\section{Table 4}

\section{Effect of central bank corporate bond purchases on bond financing of eligible firms: robustness}

This table reports results from the estimation of a pooled panel regression analyzing the effect of central bank corporate bond purchases on bond financing. The dependent variable is Bond Debt/Assets, i.e. the sum of senior bonds, subordinated bonds, and commercial paper scaled by total assets. Column 1 uses the announcement of the PSPP in January 2015 as a placebo event. That is, Post equals one after Q1 2015, and zero otherwise, and the sample period is Q1 2014 to Q4 2015. In columns 2-4, Post equals one after the CSPP announcement, i.e. after Q1 2016, and zero otherwise, and the sample period is Q1 2015 to Q1 2017. Column 2 analyzes the effect of central bank corporate bond purchases on bond debt by rating letter. $A A A-A$ Rating equals one for firms with a credit rating between $\mathrm{AAA}$ and $\mathrm{A}$, and zero otherwise. $B B B / B B / B$ Rating equals one for firms with a credit rating of $\mathrm{BBB} / \mathrm{BB} / \mathrm{B}$, and zero otherwise. "Not rated" is the omitted category. In column 3, nearest neighbor matching is used to choose for each treatment for the control firm (non-IG-rated eurozone firms with public debt) that is closest in terms of size, profitability, bond debt, and bank debt, in the pre-treatment period. The maximum permitted difference in the probability of receiving treatment (being eligible under CSPP) between matched subjects is 1\%. In column 4, European non-eurozone 1 firms are used as an alternative control group. The same nearest neighbor matching is applied to choose a non-eurozone control firm for each treatment firm. The regressions include firm-level controls to control for the heterogeneity in firm characteristics (cf. Table 2) when indicated. All variables are defined in Appendix A.2. The regressions further include firm fixed effects, industry x quarter fixed effects, and country x quarter fixed effects, when indicated. We report t-values based on standard errors clustered at the firm level in parentheses. ${ }^{* *}, * *, *$ denote significance at the 1,5 and $10 \%$ level, respectively.

\section{Placebo test (PSPP: January 2015)}

\section{(1)}

Variable:

AAA-A Rating $x$ Post 0.0062

BBB Rating x Post

BB Rating x Post

B Rating x Post

Not Rated x Post

2-digit SIC x Quarter FE

Country x Quarter FE

Firm FE

Controls

Observations

$\mathrm{BBB}=\mathrm{BB}$ ? (p-value)

\section{Discontinuity}

(2) Bond Debt/Assets

(1.74)

$0.0228 * * *$

(3.56)

$-0.0027$

$(-0.23)$

0.0092
$(0.64)$

(omitted)
Matched control group

(3)

Bond Debt/Assets
Control group: non-eurozone IG

(4) Bond Debt/Assets

\begin{tabular}{cc} 
Yes & Yes \\
Yes & No \\
Yes & Yes \\
Yes & Yes \\
1,028 & 1,022 \\
\hline
\end{tabular}




\section{Table 5}

\section{Central bank corporate bond purchases and real effects for eligible firms}

This table reports results from the estimation of a pooled panel regression analyzing the effect of central bank corporate bond purchases on asset growth, cash holdings, investments, and payouts. Asset growth is defined as the change in assets scaled by lagged total assets. $\Delta$ Cash/Lagged Assets is defined as the change in cash and shortterm investments scaled by lagged total assets $\triangle$ WorkCap/Lagged Assets is defined as the change in working capital scaled by lagged total assets. CapEx/Lagged Assets is defined as capital expenditure scaled by lagged total assets. Acq/Lagged Assets is defined as investment in cash acquisitions scaled by lagged total assets. Share Rep. is a dummy variable that equals one if a firm announces a share repurchase program in quarter $t$, and zero otherwise. AAA-A Rating equals one for eurozone firms rated AAA to A, and zero otherwise. BBB Rating equals one for eurozone firms rated BBB, and zero otherwise. Post equals one after the CSPP announcement, i.e. after Q1 2016, and zero otherwise. The sample period is Q1 2015 to Q1 2017. The regressions include firm-level

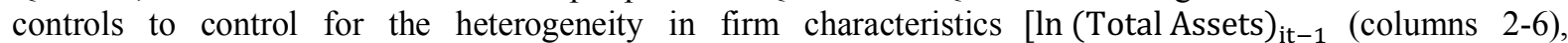
Leverage $_{\text {it-1 }}$, Profitability ${ }_{\text {it-1 }}$, Tangibility Tt-1 $_{\text {it }}$. All variables are defined in Appendix A.2. The regressions further include firm fixed effects, industry x quarter fixed effects, and country x quarter fixed effects. We report $\mathrm{t}$-values based on standard errors clustered at the firm level in parentheses. ${ }^{* * *}, * *{ }^{*}$ denote significance at the 1,5 and $10 \%$ level, respectively.

\begin{tabular}{lcccccc} 
& $(1)$ & $(2)$ & $(3)$ & $(4)$ & $(5)$ & $(6)$ \\
Variable: & $\begin{array}{c}\text { Asset } \\
\text { Growth }\end{array}$ & $\begin{array}{c}\Delta \text { Cash } \\
\text { / Lagged } \\
\text { Assets }\end{array}$ & $\begin{array}{c}\Delta \text { WorkCap } \\
\text { / Lagged } \\
\text { Assets }\end{array}$ & $\begin{array}{c}\text { CapEx } \\
\text { / Lagged } \\
\text { Assets }\end{array}$ & $\begin{array}{c}\text { Acq } \\
\text { / Lagged } \\
\text { Assets }\end{array}$ & $\begin{array}{c}\text { Share } \\
\text { Rep. }\end{array}$ \\
\hline AAA-A Rating x Post & $0.0091^{*}$ & 0.0035 & 0.0068 & 0.0007 & $0.0021^{*}$ & 0.0258 \\
& $(1.96)$ & $(0.92)$ & $(1.21)$ & $(1.00)$ & $(1.75)$ & $(1.55)$ \\
BBB Rating x Post & 0.0056 & 0.0009 & 0.0062 & 0.0005 & -0.0015 & -0.0033 \\
& $(1.21)$ & $(0.26)$ & $(1.32)$ & $(0.81)$ & $(-1.27)$ & $(-0.26)$ \\
2-digit SIC x Quarter FE & & & & & & \\
Country x Quarter FE & Yes & Yes & Yes & Yes & Yes & Yes \\
Firm FE & Yes & Yes & Yes & Yes & Yes & Yes \\
Controls & Yes & Yes & Yes & Yes & Yes & Yes \\
Observations & 6,293 & 6,296 & 6,280 & 5,794 & 6,309 & 6,309 \\
\hline $\begin{array}{l}\text { AAA-A }=\text { BBB Rating? } \\
\text { (p-value) }\end{array}$ & & & & & \\
\hline \hline
\end{tabular}




\section{Table 6}

\section{Spillovers of central bank corporate bond purchases: bank lending to non-eligible firms}

This table provides results of DiD regressions analyzing the probability (and volume) of loan issuances before versus after the introduction of a central bank corporate bond purchase program. The analysis is based on data on the borrower-bank-time level. The sample period is Q1 2015 to Q1 2017. The sample is collapsed to a preperiod and a post-period (loans issued before/after the CSPP announcement on March 10, 2016), i.e. the panel comprises two observations per borrower-firm pair. $\operatorname{pr}$ (Loan) is a dummy variable that equals one if firm $i$ receives a loan in period $t$ from bank $j$ (as lead arranger), and zero otherwise. $\ln$ (Loan Amount) is the logarithm of (one plus) the loan amount in million USD received by firm $i$ in period $t$ from bank $j$ (as lead arranger). $I G$ Share is the share of eurozone IG borrowers in the bank's term loan portfolio prior to the CSPP introduction. High IG Share is a dummy variable that equals one for banks that have a high (above-median) share of eurozone IG borrowers in their term loan portfolio prior to the CSPP introduction, and zero otherwise. Private equals one for private borrowers, and zero otherwise. In Panel A, the sample comprises both public and private borrowers. In Panel B, the sample is restricted to private borrowers. In columns 9-10 ("Placebo test"), the sample period is Q1 2014 to Q4 2015 and Post equals one after the announcement of the PSPP, i.e. after January 2015, and zero otherwise. Columns 11-12 test for a potential effect of the TLTRO-II implementation in June 2016. TLTRO-II Bank is an indicator variable that equals one for TLTRO-II borrowers, and zero otherwise. TLTROII Country is defined as total country-level TLTRO-II take-up amount in \% of the country's GDP. The base effects TLTRO-II Bank $x$ Post and TLTRO-II Country x Post are included in the estimations but not reported to save space. All variables are defined in Appendix A.2. The regressions further include borrower $\mathrm{x}$ bank fixed effects, borrower x period fixed effects, and bank x period fixed effects, when indicated. We report t-values based on standard errors clustered at the bank level in parentheses. $* * *, * * *$ denote significance at the 1,5 and $10 \%$ level, respectively.

Panel A. Sample: public and private borrowers

\begin{tabular}{|c|c|c|c|c|c|c|}
\hline Variable: & $\begin{array}{c}(1) \\
\operatorname{pr}(\text { Loan })\end{array}$ & $\begin{array}{c}(2) \\
\operatorname{pr}(\text { Loan })\end{array}$ & $\begin{array}{c}(3) \\
\operatorname{pr}(\text { Loan })\end{array}$ & $\begin{array}{c}(4) \\
\ln (\text { Loan } \\
\text { Amount) }\end{array}$ & $\begin{array}{c}(5) \\
\operatorname{pr}(\text { Loan })\end{array}$ & $\begin{array}{c}(6) \\
\ln (\text { Loan } \\
\text { Amount) }\end{array}$ \\
\hline IG Share $\mathrm{x}$ Private $\mathrm{x}$ Post & & $\begin{array}{c}0.2160^{*} \\
(1.74)\end{array}$ & $\begin{array}{c}0.2899^{* *} \\
(2.28)\end{array}$ & $\begin{array}{c}1.0955^{*} \\
(1.89)\end{array}$ & & \\
\hline High IG Share $\mathrm{x}$ Private $\mathrm{x}$ Post & & & & & $\begin{array}{c}0.0717 * * \\
(2.29)\end{array}$ & $\begin{array}{c}0.2546^{*} \\
(1.97)\end{array}$ \\
\hline IG Share $\mathrm{x}$ Post & $\begin{array}{c}-0.0184 \\
(-0.32)\end{array}$ & $\begin{array}{c}-0.1148 \\
(-1.41)\end{array}$ & & & & \\
\hline Bank x Firm FE & Yes & Yes & Yes & Yes & Yes & Yes \\
\hline Firm x Period FE & Yes & Yes & Yes & Yes & Yes & Yes \\
\hline Bank x Period FE & No & No & Yes & Yes & Yes & Yes \\
\hline Observations & 7,524 & 7,524 & 7,518 & 7,518 & 7,518 & 7,518 \\
\hline
\end{tabular}

Panel B. Sample: private borrowers only

\section{Placebo test (PSPP: January 2015)}

(7)

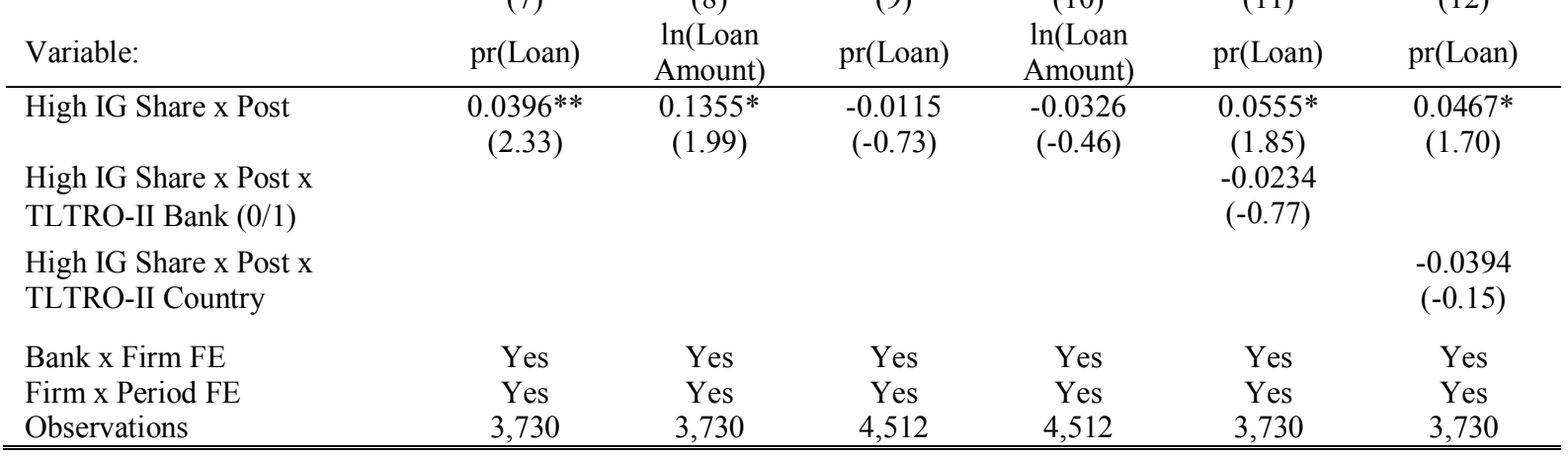

\section{TLTRO-II}

(Th) 


\section{Table 7}

\section{Bank characteristics: High IG Share vs Low IG Share banks}

This table reports summary statistics for bank characteristics (fiscal year end 2015, except for the TLTRO-II bank indicator). High IG Share (Low IG Share) refers to banks that have an above (below) median share of eurozone IG borrowers in their term loan portfolio prior to the CSPP introduction, and zero otherwise. In our sample, 31 banks take part in the European Banking Authority stress test and transparency exercises. We use the results from the transparency exercise as of December 31, 2015 to calculate the sovereign exposure measures for these banks. All variables are defined in Appendix A.2.

Low IG Share

High IG Share

\begin{tabular}{|c|c|c|c|c|c|c|c|c|c|}
\hline & Mean & Median & Std. D. & $\mathrm{N}$ & Mean & Median & Std. D. & $\mathrm{N}$ & $\begin{array}{c}\text { Diff. in means } \\
\text { (p-val.) }\end{array}$ \\
\hline \multicolumn{10}{|l|}{ Capitalization } \\
\hline Tier 1 Ratio $(\%)$ & 16.64 & 14.75 & 5.25 & 26 & 15.68 & 14.65 & 4.31 & 29 & 0.461 \\
\hline Tier 1 Common Ratio (\%) & 15.42 & 13.94 & 5.04 & 27 & 14.55 & 13.19 & 4.50 & 29 & 0.497 \\
\hline Total Capital Ratio (\%) & 19.41 & 17.96 & 5.54 & 27 & 18.55 & 17.55 & 4.23 & 29 & 0.516 \\
\hline Equity/Assets (\%) & 6.45 & 6.12 & 2.14 & 29 & 6.35 & 5.66 & 2.50 & 29 & 0.874 \\
\hline RWA/Assets (\%) & 35.25 & 37.38 & 12.39 & 26 & 35.27 & 32.27 & 12.24 & 29 & 0.993 \\
\hline \multicolumn{10}{|l|}{ Asset Quality } \\
\hline NPL/Total Loans (\%) & 6.22 & 4.64 & 5.94 & 28 & 5.77 & 4.09 & 5.74 & 26 & 0.777 \\
\hline Loan Loss Reserves/Loans (\%) & 3.66 & 1.96 & 3.67 & 28 & 2.83 & 1.82 & 2.47 & 28 & 0.322 \\
\hline \multicolumn{10}{|l|}{ Profitability } \\
\hline ROAA (\%) & 0.24 & 0.31 & 0.37 & 29 & 0.35 & 0.36 & 0.31 & 29 & 0.241 \\
\hline ROAE (\%) & 4.74 & 5.10 & 6.27 & 29 & 6.27 & 6.83 & 4.86 & 29 & 0.305 \\
\hline \multicolumn{10}{|l|}{ Liquidity } \\
\hline Loans/Deposits (\%) & 258.37 & 112.80 & 398.16 & 29 & 170.41 & 120.94 & 236.24 & 29 & 0.311 \\
\hline \multicolumn{10}{|l|}{ Investments } \\
\hline Total Assets & 397.98 & 206.97 & 496.82 & 29 & 610.74 & 500.26 & 524.25 & 29 & 0.118 \\
\hline Retail Loans/Assets (\%) & 31.13 & 35.15 & 10.87 & 17 & 25.69 & 29.61 & 14.78 & 14 & 0.247 \\
\hline Corporate Loans/Assets (\%) & 26.26 & 24.82 & 9.38 & 17 & 28.38 & 25.45 & 13.78 & 14 & 0.615 \\
\hline Sovereign Debt Home Bias (\%) & 38.41 & 31.76 & 32.27 & 12 & 48.61 & 55.15 & 24.79 & 21 & 0.316 \\
\hline Sovereign Debt Holdings (bn $€$ ) & 61.93 & 23.38 & 83.97 & 12 & 48.32 & 34.92 & 39.33 & 21 & 0.529 \\
\hline TLTRO-II Bank $(0 / 1)$ & 0.375 & 0.00 & 0.492 & 32 & 0.344 & 0.00 & 0.483 & 32 & 0.798 \\
\hline
\end{tabular}




\section{Table 8}

\section{Spillovers of central bank corporate bond purchases: bank constraints}

This table provides results of DiD regressions analyzing the probability of loan issuances before versus after the introduction of a central bank corporate bond purchase program. The analysis is based on data on the borrowerbank-time level. The sample period is Q1 2015 to Q1 2017. The sample is collapsed to a pre-period and a postperiod (loans issued before/after the CSPP announcement on March 10, 2016), i.e. the panel comprises two observations per borrower-firm pair. $\operatorname{pr}($ Loan) is a dummy variable that equals one if firm $i$ receives a loan in period $t$ from bank $j$ (as lead arranger), and zero otherwise. High IG Share is a dummy variable that equals one for banks that have a high (above-median) share of eurozone IG borrowers in their term loan portfolio prior to the CSPP introduction, and zero otherwise. The sample is restricted to private borrowers. Columns 1 and 2 split the sample by a bank's Tier 1 Ratio, measured at the end of 2015. Constrained banks are defined as banks in the lowest Tier 1 Ratio tercile. The remaining banks are defined as unconstrained. Columns 3 and 4 split the sample by a bank's NPLs to total loans ratio, measured at the end of 2015. Constrained banks are defined as banks in the highest NPLs to total loans ratio tercile. The remaining banks are defined as unconstrained. All variables are defined in Appendix A.2. The regressions further include borrower x period fixed effects and bank $\mathrm{x}$ borrower fixed effects, when indicated. We report t-values based on standard errors clustered at the bank level in parentheses. $* * *, * * *$ denote significance at the 1,5 and $10 \%$ level, respectively.

\begin{tabular}{|c|c|c|c|c|}
\hline \multirow[t]{2}{*}{ Specification: } & \multicolumn{2}{|c|}{ Bank Tier 1 Ratio } & \multicolumn{2}{|c|}{ Non-performing loans/Total loans } \\
\hline & Constrained & Unconstrained & Constrained & Unconstrained \\
\hline & (1) & (2) & (3) & (4) \\
\hline Variable: & $\operatorname{pr}($ Loan $)$ & $\operatorname{pr}($ Loan $)$ & pr(Loan) & pr(Loan) \\
\hline High IG Share x Post & $\begin{array}{c}0.0805^{* * *} \\
(3.68)\end{array}$ & $\begin{array}{c}0.0228 \\
(0.85)\end{array}$ & $\begin{array}{c}0.1619 * \\
(2.03)\end{array}$ & $\begin{array}{c}0.0258 \\
(1.28)\end{array}$ \\
\hline Bank x Firm FE & Yes & Yes & Yes & Yes \\
\hline Firm $x$ Period FE & Yes & Yes & Yes & Yes \\
\hline Observations & 1,524 & 1,840 & 1,050 & 2,298 \\
\hline Coefficients equal? (p-value) & \multicolumn{2}{|c|}{$0.047 * *$} & \multicolumn{2}{|c|}{$0.036^{* *}$} \\
\hline
\end{tabular}


Table 9

Spillovers of central bank corporate bond purchases: firm-level

This table reports results from the estimation of a pooled panel regression analyzing the effect of central bank corporate bond purchases on bank lending. The analysis is based on data on the firm-year level. pr(Loan) is a dummy variable that equals one if the firm obtains a bank loan in the respective year, and zero otherwise. In(Loan Amount) is the $\log$ loan amount in USD received by the firm in the respective year. High IG Share equals one for firms whose lenders have a high (above-median) share of eurozone IG borrowers in their term loan portfolio prior to the CSPP introduction, and zero otherwise. Post equals one in 2016, and zero otherwise. The sample period is 2015 to 2016 . The sample comprises private eurozone firms in columns 1-2 and 4-7 and public eurozone firms in column 3 . The regressions include firm-level controls to control for the heterogeneity in firm characteristics [ln(Total Assets), Profitability, Tangibility], when indicated. Firm-level controls are lagged by one year. Panel B reports results by firm quality. Columns 4 and 5 split the sample by a firm's profitability, measured at the end of 2015. Columns 6 and 7 split the sample by a firm's interest coverage, measured at the end of 2015. All variables are defined in Appendix A.2. The regressions further include firm fixed effects, industry x year fixed effects, and country x year fixed effects, when indicated. We report t-values based on standard errors clustered at the firm level in parentheses. $* * *, * *, *$ denote significance at the 1,5 and $10 \%$ level, respectively.

\section{Panel A: Baseline results}

Specification:

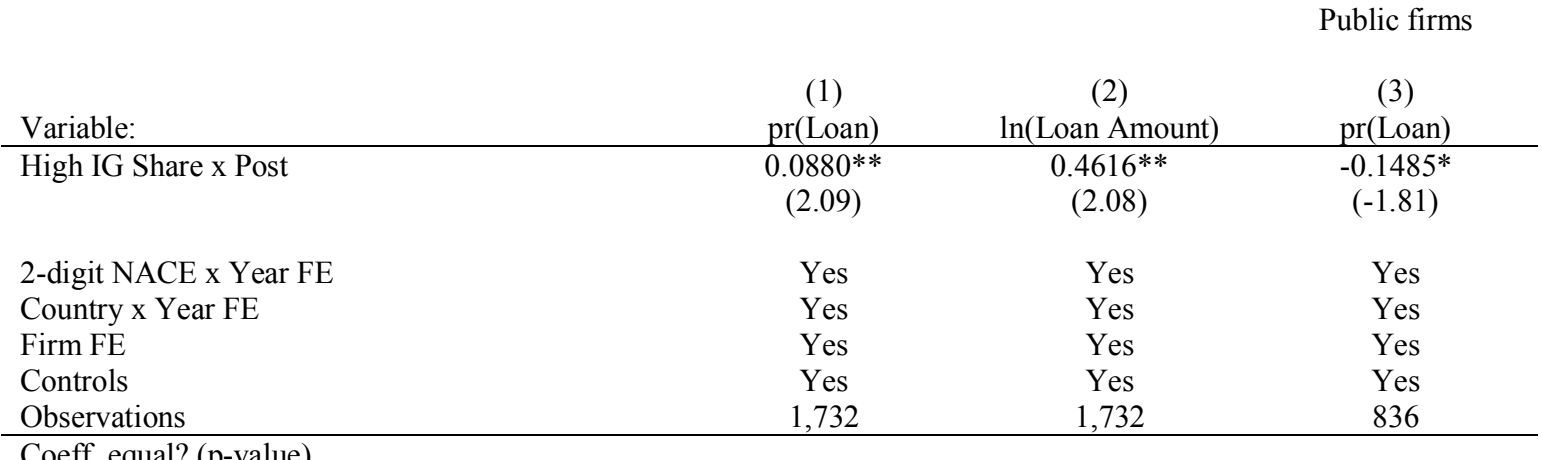

\section{Panel B: Firm quality effect}

\begin{tabular}{|c|c|c|c|}
\hline \multicolumn{2}{|c|}{ Profitability } & \multicolumn{2}{|c|}{ Interest coverage } \\
\hline$<$ Median & $>=$ Median & $<$ Median & $>=$ Median \\
\hline (4) & (5) & (6) & (7) \\
\hline $\operatorname{pr}$ (Loan) & $\operatorname{pr}$ (Loan) & $\operatorname{pr}$ (Loan) & $\operatorname{pr}$ (Loan) \\
\hline 0.0378 & $0.1300 * *$ & 0.0559 & $0.1306^{*}$ \\
\hline$(0.60)$ & $(2.14)$ & $(0.92)$ & $(1.81)$ \\
\hline Yes & Yes & Yes & Yes \\
\hline Yes & Yes & Yes & Yes \\
\hline Yes & Yes & Yes & Yes \\
\hline Yes & Yes & Yes & Yes \\
\hline 824 & 850 & 774 & 804 \\
\hline
\end{tabular}




\section{Table 10}

\section{Spillovers of central bank corporate bond purchases: real effects for non-eligible firms}

This table reports results from the estimation of a pooled panel regression analyzing the effect of central bank corporate bond purchases on asset growth, investment, and profitability. The dependent variable in column 1 is Asset Growth, defined as change in assets scaled by lagged assets. The dependent variable in column 2 is CapEx/Fixed Assets, defined as capital expenditure scaled by lagged fixed assets. High IG Share equals one for firms whose lenders have a high (above-median) share of eurozone IG borrowers in their term loan portfolio prior to the CSPP introduction (estimated over the 2010 to 2014 period), and zero otherwise. Post equals one for 2016, and zero for 2015. The sample period is 2015 to 2016. The sample comprises private eurozone firms. The regressions include firm-level controls to control for the heterogeneity in firm characteristics [ $\ln ($ Total Assets) (column 2), Profitability, Tangibility, Leverage], when indicated. Firm-level controls are lagged by one period. All variables are defined in Appendix A.2. The regressions further include firm fixed effects, industry $\mathrm{x}$ year fixed effects, and country x year fixed effects, when indicated. We report t-values based on standard errors clustered at the firm level in parentheses. $* * *, * * *$ denote significance at the 1,5 and $10 \%$ level, respectively.

\begin{tabular}{l} 
High IG Share x Post \\
High IG Share x Post x High \\
2-digit NACE x Year FE \\
Country x Year FE \\
Firm FE \\
Controls \\
Observations \\
\hline
\end{tabular}

\author{
2-digit NACE x Year FE \\ Observations
}

(1)

(2) CapEx

Asset Growth

$0.0646^{* * *}$
Fixed Assets $0.0379^{* * *}$ (2.67)

High GDP growth

$(2.72)$

(3) Asset Growth $0.0620^{*}$

(1.90)

(4)
CapEx / Fixed Assets $0.0344^{*}$ (1.93) 0.0094 $(0.34)$

\begin{tabular}{cccc} 
Yes & Yes & Yes & Yes \\
Yes & Yes & Yes & Yes \\
Yes & Yes & Yes & Yes \\
Yes & Yes & Yes & Yes \\
1,306 & 1,306 & 1,306 & 1,306 \\
\hline
\end{tabular}




\section{Appendix A.1.}

\section{Figure A.1. Bank balance sheet asset composition}

Panel A shows the share of loans, debt securities, and other assets as a fraction of total assets for monetary financial institutions (MFIs, excluding central banks) in the euro area from Q1 2015 to Q1 2017. The data are provided by the ECB's Aggregate Balance Sheet Statistics. Panel B decomposes MFIs' debt securities holdings into different categories by issuer identity (government, NFCs, and other). The data are provided by the ECB's Securities Holding Statistics.

\section{Panel A. Asset composition}

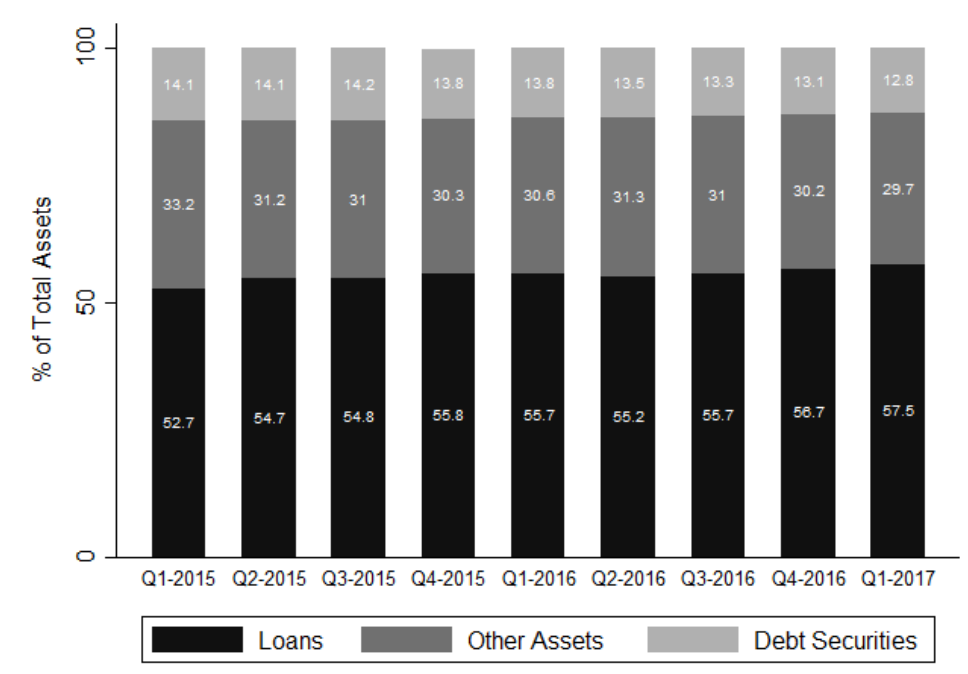

Panel B. Debt securities components

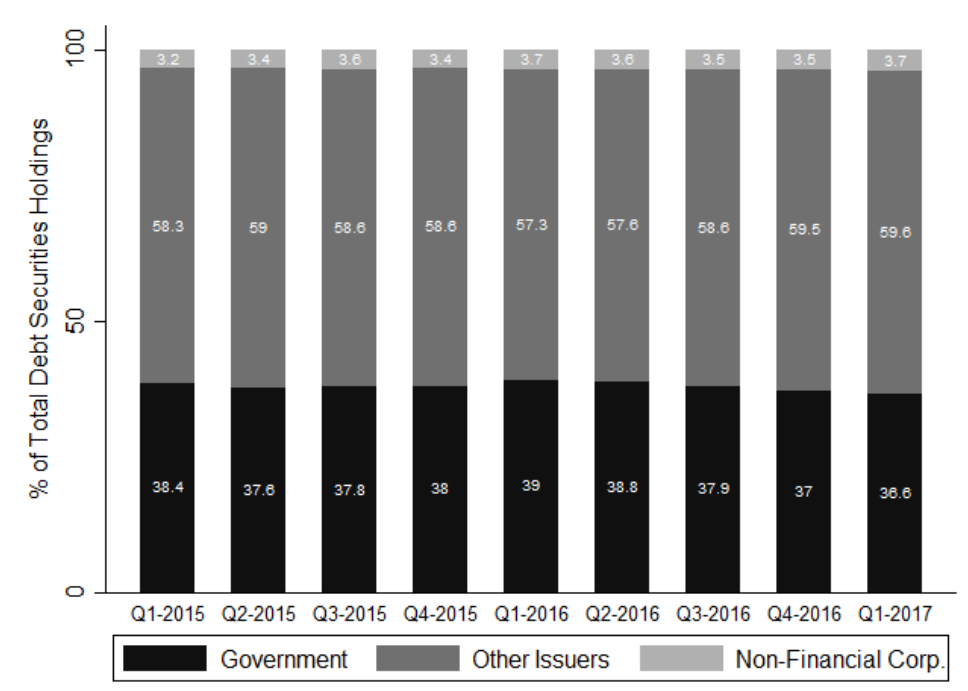


Appendix A.2.

Table A.2. Variable definitions

\begin{tabular}{|c|c|c|}
\hline Variable & Source & Description \\
\hline Total Debt/Assets & Compustat Global & Ratio of book value of debt to total assets. \\
\hline Bond Debt/Assets & $\begin{array}{l}\text { Capital IQ, Compustat } \\
\text { Global }\end{array}$ & $\begin{array}{l}\text { Ratio of bond debt (senior bonds, subordinated bonds, } \\
\text { and commercial paper) to total assets. }\end{array}$ \\
\hline Term Loans/Assets & $\begin{array}{l}\text { Capital IQ, Compustat } \\
\text { Global }\end{array}$ & Ratio of term loans to total assets. \\
\hline Revolving Credit/Assets & $\begin{array}{l}\text { Capital IQ, Compustat } \\
\text { Global }\end{array}$ & Ratio of (drawn) revolving credit to total assets. \\
\hline Profitability & $\begin{array}{l}\text { Compustat } \\
\text { Global/BvD's Amadeus }\end{array}$ & Ratio of EBITDA to total assets. \\
\hline Tangibility & $\begin{array}{l}\text { Compustat } \\
\text { Global/BvD's Amadeus }\end{array}$ & Ratio of property, plant, and equipment to total assets. \\
\hline MtB & Compustat Global & $\begin{array}{l}\text { Ratio of market value of equity to book value of } \\
\text { equity (total assets minus total debt). }\end{array}$ \\
\hline Asset Growth & $\begin{array}{l}\text { Compustat } \\
\text { Global/BvD's Amadeus }\end{array}$ & Change in assets scaled by lagged assets. \\
\hline$\Delta$ Cash/Lagged Assets & Compustat Global & $\begin{array}{l}\text { Change in cash and short-term investments to lagged } \\
\text { total assets. }\end{array}$ \\
\hline$\Delta$ WorkCap/Lagged Assets & Compustat Global & Change in working capital scaled by lagged assets. \\
\hline CapEx/Lagged Assets & Compustat Global & Capital expenditure to lagged total assets. \\
\hline Acq/Assets & Compustat Global & $\begin{array}{l}\text { Ratio of investment in cash acquisitions to lagged } \\
\text { total assets. }\end{array}$ \\
\hline Share Rep. & BvD’s Zephyr & $\begin{array}{l}\text { A dummy variable that equals one if a firm announces } \\
\text { a share repurchase program in quarter } t \text {. }\end{array}$ \\
\hline IG Share & DealScan & $\begin{array}{l}\text { Share of (non-financial) investment-grade borrowers } \\
\text { of a bank in its total term loan portfolio, measured } \\
\text { over the } 2010-2014 \text { period. }\end{array}$ \\
\hline Total Assets & SNL Financial & Total assets in billion EUR. \\
\hline Retail Loans/Assets & SNL Financial & Retail loans in percent of total assets. \\
\hline Corp. Loans/Assets & SNL Financial & Corporate loans in percent of total assets. \\
\hline Tier 1 Ratio & SNL Financial & Tier 1 ratio in percent. \\
\hline Tier 1 Common Ratio & SNL Financial & Tier 1 common capital ratio (CET1) in percent. \\
\hline Total Capital Ratio & SNL Financial & Total capital ratio in percent. \\
\hline Equity/Assets & SNL Financial & Total equity in percent of total assets. \\
\hline RWA/Assets & SNL Financial & Ratio of risk-weighted assets to total assets in percent. \\
\hline NPL/Total Loans & SNL Financial & Problem loans in percent of gross customer loans. \\
\hline Loan Loss Reserves/Loans & SNL Financial & Loan loss reserves in percent of gross loans. \\
\hline ROAA & SNL Financial & Return on average assets in percent. \\
\hline ROAE & SNL Financial & Return on average equity in percent. \\
\hline Loans/Deposits & SNL Financial & Ratio of total loans to deposits in percent. \\
\hline Sovereign Debt Home Bias & EBA & $\begin{array}{l}\text { Percentage of domestic sovereign bonds (31 Dec } \\
\text { 2015). }\end{array}$ \\
\hline Sovereign Debt Holdings & EBA & Total sovereign bond holdings (31 Dec 2015). \\
\hline TLTRO-II Bank & Bloomberg & $\begin{array}{l}\text { An indicator variable for banks that disclose TLTRO- } \\
\text { II borrowings. }\end{array}$ \\
\hline TLTRO-II Country & National Central Banks & $\begin{array}{l}\text { Country-level TLTRO-II take-up amount in } \% \text { of the } \\
\text { country's GDP. }\end{array}$ \\
\hline $\operatorname{pr}($ Loan $)$ & DealScan & $\begin{array}{l}\text { A dummy variable that equals one if a firm obtains a } \\
\text { bank loan in period } t \text {, and zero otherwise. }\end{array}$ \\
\hline Loan Amount & DealScan & $\begin{array}{l}\text { Total loan amount obtained by a firm in period } t \text { in } \\
\text { million USD. }\end{array}$ \\
\hline CapEx/Fixed Assets & BvD's Amadeus & $\begin{array}{l}\text { Change in fixed assets plus depreciation scaled by } \\
\text { lagged fixed assets. }\end{array}$ \\
\hline Interest Coverage & BvD's Amadeus & Interest expenses to EBIT. \\
\hline Yield Spread & Dealogic, Datastream & $\begin{array}{l}\text { Yield-to-maturity minus maturity-matched swap } \\
\text { spread. }\end{array}$ \\
\hline Loan Spread & DealScan & All-in-spread-draw in basis points. \\
\hline
\end{tabular}

